\title{
The Role of PPAR $\gamma$ in Cardiovascular Diseases
}

\author{
M. KVANDOVÁ ${ }^{1}$, M. MAJZÚNOVÁ ${ }^{1}$, I. DOVINOVÁ ${ }^{1}$ \\ ${ }^{1}$ Institute of Normal and Pathological Physiology, Slovak Academy of Sciences, Bratislava, \\ Slovakia
}

Received July 1, 2016

Accepted September 5, 2016

\section{Summary}

The peroxisome proliferator-activated receptors (PPAR) belong to the nuclear superfamily of ligand-activated transcription factors. PPARy acts as a nutrient sensor that regulates several homeostatic functions. Its disruption can lead to vascular pathologies, disorders of fatty acid/lipid metabolism and insulin resistance. PPARY can modulate several signaling pathways connected with blood pressure regulation. Firstly, it affects the insulin signaling pathway and endothelial dysfunction by modulation of expression and/or phosphorylation of signaling molecules through the PI3K/Akt/eNOS or MAPK/ET-1 pathways. Secondly, it can modulate gene expression of the reninangiotensin system - cascade proteins, which potentially slow down the progression of atherosclerosis and hypertension. Thirdly, it can modulate oxidative stress response either directly through PPAR or indirectly through Nrf2 activation. In this context, activation and functioning of PPARy is very important in the regulation of several disorders such as diabetes mellitus, hypertension and/or metabolic syndrome.

\section{Key words}

PPARY • Hypertension • Oxidative stress $\bullet$ Antioxidant response • Renin-angiotensin system • Nitric oxide

\section{Corresponding author}

I. Dovinova, Institute of Normal and Pathological Physiology, Slovak Academy of Sciences, Sienkiewiczova 1, 81371 Bratislava, Slovak Republic. E-mail: ima.dovinova@savba.sk

\section{Introduction}

Peroxisome proliferator-activated receptors (PPAR) belong to the nuclear superfamily of ligandactivated transcription factors. The name of this group of nuclear receptors was derived from their ability to stimulate proliferation of peroxisomes in rats (Issemann and Green 1990). In humans, three isoforms of nuclear receptors were discovered: PPAR $\alpha, \operatorname{PPAR} \beta / \delta$ and PPAR $\gamma$, which differ in their distribution and specific function (Leonardini et al. 2009). PPAR activation leads to transactivation and transrepression of selected gene expression. Ligand-activated PPAR creates heterodimer with the retinoic $\mathrm{X}$ receptor, which is subsequently bound on sequence-specific target element in promotor region of target genes (Oyekan 2011).

PPARs are nutrient sensors that regulate a number of homeostatic functions, such as glucose and lipid metabolism by uptake, utilization, oxidation and storage of fatty acids. It was found that PPAR $\gamma$ as a nutrient-sensing signaling sensor can influence nutritional programming of hypertension and metabolic syndrome (Tain et al. 2016). PPARs participate in the regulation of cell growth, migration and apoptosis and they may modulate oxidative stress, antioxidant response and inflammatory diseases in cardiovascular system (Chen et al. 2008, Oyekan 2011, Polvani et al. 2012). Disruptions of these pathways can result in the development of several diseases and pathological states, such as obesity, obesity-induced inflammation, atherosclerosis, diabetes mellitus, metabolic syndrome and hypertension (Duan et al. 2009, Oyekan 2011, Kiss et al. 2013, Montanez et al. 2013). 


\section{Post-translational modifications of PPAR $\gamma$}

Up to this day, seven diverse mRNA transcripts of PPAR $\gamma(\gamma 1-\gamma 7)$ were found, which are generated with different initiation types and alternative splicing of exons - five exons in terminal region (Chen et al. 2006, Christodoulides and Vidal-Puig 2010) and six exons in the open reading frame. Only PPAR $\gamma 1$ is expressed in heart and skeletal muscle, vascular smooth muscle cells and endothelial cells (Das and Chakrabarti 2006, Chen et al. 2006, Li and Wang 2007), while isoforms PPAR $\gamma 2$ or PPAR $\gamma 4$ are primary delimited in adipose tissue or freely presented in macrophages, colon and in adipocytes (Chen et al. 2006).

The action of PPAR $\gamma$ is regulated by posttranslation modifications such as phosphorylation, acetylation, SUMOylation and/or ubiquitination that represent a potentially distinct feature of PPAR $\gamma$ and could be exploited for tissue-specific distribution and function (van Beekum et al. 2009). Phosphorylation by MAPK inhibits ligand binding (Hu et al. 1996, Zhang et al. 1996, Camp and Tafuri 1997) or increases the activity of PPAR $\gamma$ by the cyclin-dependent kinases (Compe et al. 2005, Iankova et al. 2006).

Likewise, PPAR $\gamma$ activity regulation is controlled by covalent attachment of small ubiquitin-like modifier (SUMO). SUMOylation is one of the posttranslational modification responsible for the regulation of stability, nuclear-cytosolic distribution and activity of transcription factors at different Lys residues (Pascual et al. 2005, Shimizu et al. 2006, Kim et al. 2013).

Ubiquitination is yet another level of control over PPAR $\gamma$ activity. In the nucleus of adipocytes, the PPAR 2 protein level is decreased by the action of thiazolidinediones (TZDs). The degradation occurs in an ubiquitin-dependent manner in the AF-2 domain of PPAR $\gamma$. However, the AF- 1 domains of PPAR $\gamma 1$ and PPAR $\gamma 2$ are degraded by the REG $\gamma$ proteasome, the type of proteasome that degrades the target substrate in an ubiquitin- and ATP-independent fashion. The PPAR $\gamma$ protein (with a short half-life time of $\sim 2$ hours) is polyubiquitinated and subsequent degraded by the proteasome (Hauser et al. 2000).

\section{PPAR $\gamma$-deficient and transgenic mice}

Human genetic studies have revealed that PPAR $\gamma$ mutation in humans can result in either a gain or a loss of function. Pro ${ }^{12}$ Ala mutation can result in a loss of function mutation and has been reported to be associated with increased protection against insulin resistance and diabetes type 2 (Mori et al. 2001, Lindi et al. 2002) and a decreased incidence of myocardial infarction and/or lower diastolic blood pressure (BP) (Ostgren et al. 2003). On other hand, several other mutations such as $\mathrm{Pro}^{467}$ Leu, Val ${ }^{290}$ Met, Phe ${ }^{388}$ Leu and $\mathrm{Arg}^{425} \mathrm{Cys}$ are all involved in loss of function mutations and have been associated with partial lipodystrophy, insulin resistance, diabetes and hypertension (Barroso et al. 1999, Agarwal and Garg 2002, Hegele et al. 2002). The ligand binding domain mutants of PPAR $\gamma$ with dominant negative actions stimulate associations with the nuclear receptor corepressor (N-CoR) and the silencing mediator of retinoid and thyroid receptors (SMRT) and they inhibit activities of all three PPAR isoforms (Semple et al. 2005).

It was shown that PPAR $\gamma$ is required for placental, cardiac and adipose tissue development. PPAR $\gamma$ null mouse surviving to term following placental reconstitution exhibited a phenotypic array that included lipodystrophy, fatty liver and hemorrhages, with fatal consequences during the first week of life (Barak et al. 1999). Increased cardiac hypertrophy and/or blood pressure decrease were observed in cardiac knockout mice or generalized knockout mice (Duan et al. 2005, Duan et al. 2007)

\section{PPAR $\gamma$ and mechanisms of blood pressure regulation in hypertension and metabolic syndrome}

Activation of PPAR $\gamma$ plays an essential role in the regulation of eNOS expression in endothelial cells and increases bioavailability of the nitric oxide (NO) (Nagao and Yamaguchi 2012). Vascular PPAR $\gamma$ is known also as peripheral regulator of the cardiovascular rhythm. PPAR $\gamma$ controls circadian variation in blood pressure and heart rate via the BMAL-1 (Brain and muscle Arnt-like protein-1) protein (Wang et al. 2008) and is an important component of the "vascular clock". Pioglitazone (PIO), the PPAR $\gamma$ agonist, modifies BP circadian rhythm in patients with diabetes mellitus type 2 from non-dippers (patients without $10 \% \mathrm{BP}$ decrease at night) to dippers (patients with $10 \%$ or higher BP decrease at night) (Anan et al. 2007). PPAR $\gamma$ can play an important role in the regulation of vascular homeostasis. Disruption of PPAR $\gamma$ function in these processes can contribute to vascular pathologies, such as atherosclerosis, restenosis and 
hypertension (Li and Wang 2007, Burris et al. 2012).

It was found that TZDs can decreases BP in nondiabetic hypertensive patients (Raji et al. 2003) as well as in diabetic patients (Shargorodsky et al. 2003). Moreover, TZDs improve endothelial dysfunction in rat mesenteric resistance arteries after angiotensin II (Ang II) infusions (Diep et al. 2002). The beneficial pleiotropic action of PPAR $\gamma$ on the vasculature are glycemia-independent (Sugawara et al. 2010). This effect can occur via several mechanisms comprising PPAR $\gamma$-mediated modulation of expression and/or phosphorylation of specific signaling molecules of the insulin signaling pathway. This PPAR $\gamma$ dependent modulation of insulin receptor signaling can lead to re-establishment of the balance between PI3K/Akt/eNOS and MAPK/ET-1, with a subsequent increase of NO bioavailability and vasodilatation ( $\mathrm{Li}$ and Wang 2007).

Furthermore, PPAR $\gamma$ can directly modulate gene expression of antioxidant and prooxidant genes and maintain redox homeostasis via interaction between PPAR $\gamma$ and the signaling pathways involved in oxidative stress modulation. It is an example of cooperation of signaling pathways, such as Nrf2 (Nuclear factor E2-related factor 2), NF- $\mathrm{B}$ (nuclear factor kappa B), Wnt (Wingless-type MMTV integration site)/ $\beta$-catenin and FOXO (forkhead box protein O) proteins (Polvani et al. 2012). PPAR $\gamma$ activation can decrease oxidative stress in rostral ventrolateral medulla, which plays a critical role in pathogenesis of hypertension (Chan et al. 2010). Modulation of oxidative stress can slow down the development of hypertension in the prehypertensive period (Dovinova et al. 2013).

In addition, PPAR $\gamma$ can inhibit gene expression of the $\mathrm{AT}_{1}$ receptor and, through Ang II, induce ERK 1/2 activation and subsequent inhibition of vascular remodeling (Benkirane et al. 2006). PPAR $\gamma$ activation can inhibit the renin-angiotensin system (RAS) and decrease BP (Roszer and Ricote 2010).

\section{PPAR $\gamma$ and the PI3K/Akt/eNOS signaling pathway}

Insulin resistance is the reduction of sensitivity and/or response to metabolic activation of the insulin receptor and is associated with a variety of metabolic disease and hemodynamic disruptions. A reciprocal relationship between insulin resistance and endothelial dysfunction was observed in animal experimental models and in human studies (Koh et al. 2005, Koh et al. 2006).
Insulin plays an essential role in the control of glucose homeostasis in skeletal muscles, adipose tissue and liver. It is involved in blood flow regulation and maintenance of vascular health. The most important effect of insulin on the cardiovascular system is the stimulation of NO production in the vascular endothelium. Abnormal reduction of insulin sensitivity affects vascular homeostasis, with manifestations such as impaired endothelial function, vasodilation, enhanced vascular inflammation and atherosclerotic lession formation.

Insulin is synthesized in pancreatic $\beta$-cells in the islets of Langerhans in response to increased glycemia after a meal from a precursor - preproinsulin (Sharma et al. 2008). Preproinsulin, 110-amino acids long, contains an N-terminal signal peptide that facilitates transfer of signal recognition particles into the lumen of the rough endoplasmic reticulum. The signal peptide of preproinsulin is subsequently cleaved away by a signal peptidase into proinsulin. Proinsulin folds in the oxidizing environment and the folded proinsulin is transported to the Golgi apparatus in immature secretory vesicles where is cleaved down to insulin and C-peptide (Fu et al. 2013). The insulin signaling pathway is activated through insulin binding to the insulin receptor (IR). The binding of insulin leads to conformation changes in the intrinsic tyrosine kinase of $\beta$ transmembrane subunits of the insulin receptor as well as the tyrosine phosphorylation of multiple docking proteins, including insulin receptor substrates 1 (IRS1) and 2 (IRS2) (Fig. 1a). IRS1 is necessary for insulinstimulated NO production in the endothelium. IRS1 and IRS2 are not functionally redundant, although they both activate many similar downstream pathways (Waters and Pessin 1996, Hanke and Mann 2009). IRS2 may contribute to NO production, but is primarily implicated in the delivery of insulin to skeletal muscle interstitium (Arce-Esquivel et al. 2013).

IRS2 is a widely expressed protein that regulates crucial biological processes including glucose metabolism, protein synthesis and cell survival. IRS2 is a part of the insulin signaling pathway and mediates the activation of the NO or ET-1 through PI3K/Akt or Ras/MAPK in insulin target tissues and in the pancreas (Oliveira et al. 2014). The role of the muscle vasculature is beginning to be appreciated as a factor that influences the myocyte response to insulin. Insulin signaling plays a critical role in glucose disposal in skeletal muscle (DeFronzo et al. 1985). In cultured myocytes, insulin 
activates insulin receptor and IRS2 proteins and stimulates glucose uptake in within minutes (Sarabia et al. 1990, Sarabia et al. 1992, Ogihara et al. 1997). Loss of skeletal muscle capillary density is observed in both insulin resistance and in type 2 diabetes, while insulin action is positively correlated with capillary density (Lillioja et al. 1987). Insulin-stimulated increases in blood flow or increased recruitment of perfused capillaries are both dependent on nitric oxide (NO) production and may augment insulin delivery to the interstitium because NO has been shown to mediate insulin-stimulated capillary recruitment (Kubota et al. 2011).

IRS1 or IRS2 phosphorylation leads to the activation of two signaling pathways: PI3K/Akt/eNOS and MAPK/ET-1 (Fig. 1a). The tyrosine phosphorylated
IRS1 activates phosphatidylinositol 3-kinase (PI3K) through phosphorylation of the src homology 2 (SH2) domain of the $\mathrm{p} 85$ regulatory subunit of PI3K. Activation of the p110 subunit of PI3K cleaves catalytically the membrane phospholipid phosphatidylinositol 4,5bisphosphate (PIP2) to phosphatidylinositol 3,4,5trisphosphate (PIP3). PIP3 is needed for PIP3-dependent phosphorylation of PDK1 (3'-phosphoinositide-dependent kinase-1) and Akt kinase. Finally, Akt kinase phosphorylates several effector proteins, including GSK$3 \beta$, FOXO and eNOS. GSK-3 $\beta$ activation is insulinindependent, but it may be activated through the insulin signaling pathway. GSK-3 $\beta$ phosphorylation through IRS1 activation and PKB inhibition is more present in basal conditions compared to insulin receptor stimulation (Copps and White 2012).
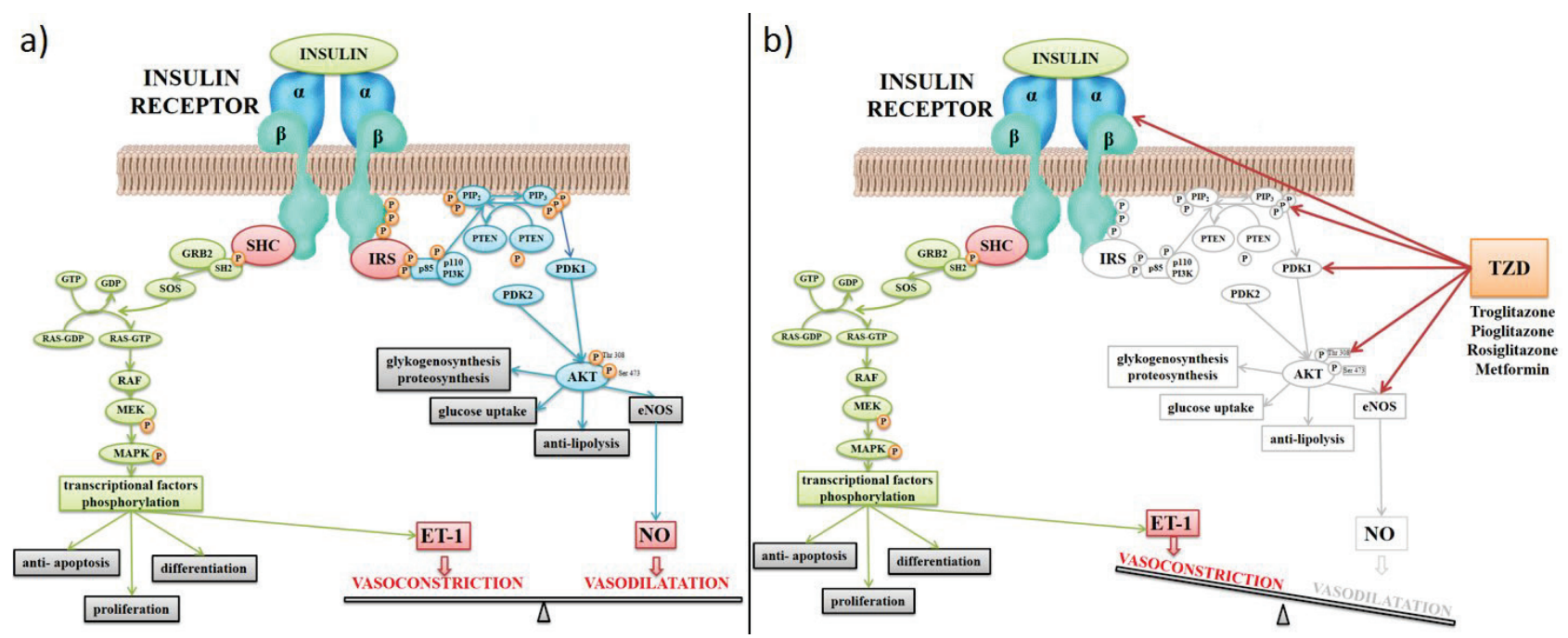

Fig. 1. Activation of the insulin signaling pathway and the effect of TZD-activated PPARY. a) Activation of the insulin signaling pathway and the effect of insulin on vascular tone. b) Activation of PPARY by TZDs. PPARy activation affects the insulin signaling pathway by modulation of expression and/or phosphorylation of specific signaling molecules, which can lead to reestablishment of balance between the vasodilator and vasoconstrictor effects due to insulin receptor activation resulting in an improvement of insulin sensitivity.

$\mathrm{PI} 3 \mathrm{~K} / \mathrm{Akt} / \mathrm{eNOS}$ signaling pathway is critical point for vascular tone regulation, because eNOS catalyzes the conversion of L-arginine to L-citrulline and produces NO. On the other hand, MAPK cascade activation plays an important role in insulin-regulated mitogen processes, such as cell proliferation, cell differentiation and cell survival (Kim and Choi 2010).

The balance between vasodilator and vasoconstrictor effects induced by the activation of insulin receptor is disrupted in vascular endothelium cells of insulin resistance animal models. PI3K/Akt/eNOS signaling pathway is suppressed while signaling pathway MAPK/ET-1 is preserved (Kobayashi et al. 2004). This balance disruption is called endothelial dysfunction (Mitchell et al. 2008). TZDs activation of PPAR $\gamma$ improves insulin sensitivity in diabetic patients, leading to the reduction of plasma insulin and glucose levels (Fig. 1b). PPAR $\gamma$ activation affects insulin signaling pathway by modulation of expression and/or phosphorylation of specific signaling molecules, which can lead to reestablishment of balance between vasodilator and vasoconstrictor effects due to insulin receptor activation.

Li et al. (2010) showed that PI3K expression and phosphorylation of PKB-eNOS in vascular tissues is decreased in the young male spontaneously hypertensive 
rats (SHR). Administration of rosiglitazone (RSG) raises vascular PPAR $\gamma$ expression, resulting in restoration of $\mathrm{PI} 3 \mathrm{~K} / \mathrm{PKB} / \mathrm{eNOS}$ signaling activation, followed by the improvement of endothelial function in the young SHR due to increased NO release (Li et al. 2010).

In clinical practice, synthetic ligands are used. Synthetic PPAR $\gamma$ ligands are TZD derivates. They are selective agonists of nuclear receptor PPAR $\gamma$ and they are used for insulin sensitivity improvement in patients with diabetes mellitus type 2 (Nakamura et al. 2000, Fruchart et al. 2001, Taniguchi et al. 2001), while TZDs activate minimally PPAR- $\alpha$ and PPAR- $\beta$ isoforms (Willson et al. 1996). TZDs treatment can influence and change the expression of signaling molecules of the insulin signaling cascade (IRS, PI3K, Akt, eNOS, 5'-AMP kinase, GLUT4, etc.) connected with improvement of insulin sensitivity and/or endothelial dysfunction.

TZDs comprise troglitazone, rosiglitazone, pioglitazone and tideglusib. Troglitazone was approved in 1997, but it was withdrawn from the market for increased risk of liver failure and extensive hepatotoxicity in 2000 (Kohlroser et al. 2000). Tideglusib is a potent, irreversible, non ATP-competitive glycogen synthase kinase-3 $\beta$ (GSK-3 $\beta$ ) inhibitor and PPAR $\gamma$ agonist tideglusib seems to be suitable candidate for Alzheimer disease treatment or for a treatment of stroke (Armagan et al. 2015), but its application in cardiovascular disease treatment has not been examined yet.

The effectiveness of other two TZDs pioglitazone and rosiglitazone are similar in treatment of diabetes mellitus type 2, but they differ in the treatment of cardiovascular diseases. The PROactive study points out the positive effect of PIO (reduced cardiovascular complications by $16 \%$ ) in cardiovascular disease patients (Dormandy et al. 2009), while RSG treatment was associated with increased incidence of myocardial infarction and death after a relatively short-term exposure (Nissen and Wolski 2007). The European Medicines Agency withdrew its approval of this medication in 2010 due to cardiovascular safety concerns (Krishnaswami et al. 2010).

\section{PPAR $\gamma$ in adipose tissue and insulin resistance}

$\operatorname{PPAR} \gamma$ has tissue-specific effects. It is most highly expressed in adipose tissue. PPAR $\gamma$ upregulates genes involved in glucose uptake and also controls the expression of factors secreted by adipocytes in adipose tissue. PPAR $\gamma$ activation enhances the uptake and sequestration of fatty acids in adipose tissue and improves insulin resistance (Ahmadian et al. 2009). Members of the fibroblast growth factor family (FGF1 and FGF21) act locally in adipose tissue to mediate the physiological and pharmacological actions of PPAR $\gamma$ and to promote insulin sensitization in response to high-fat diet (Dutchak et al. 2012, Jonker et al. 2012, Sun and Scherer 2012). FGF binding to FGF receptors induces the activation of four key intracellular signaling pathways: RAS/RAF/MAPK, PI3K/Akt, STAT and PLC $\gamma$ (Beenken and Mohammadi 2009).

FGF21 is a key mediator of fatty acid oxidation and lipid metabolism. Pharmacological doses of FGF21 improve glucose tolerance, lower serum free fatty acids and lead to weight loss in obese mice. However, the expected beneficial effects of endogenous FGF21 to increase glucose tolerance and reduce circulating triglycerides are absent in obesity and leads to FGF21resistant state (Fisher et al. 2010).

In the development of cardiovascular diseases including atherosclerosis, coronary heart disease, myocardial ischemia, cardiac hypertrophy and diabetic cardiomyopathy, there is a strong evidence showing that the development is associated with an increase in serum FGF21 levels. This was regarded as a compensatory response to induced cardiac protection. Furthermore, administration of FGF21 suppressed the above cardiovascular diseases. Mechanistic studies revealed that FGF21 induced cardiac protection likely by preventing cardiac lipotoxicity and the associated oxidative stress, inflammation and apoptosis (Cheng et al. 2016).

\section{PPAR $\gamma$ and endothelial nitric oxide synthase}

The regulation of eNOS expression and its activation is influenced by various cellular events, such as transcription regulation, protein-protein interaction, phosphorylation and dephosphorylation at different amino acid sequences of eNOS regulated by various kinases and phosphatases (Govers and Rabelink 2001). eNOS has a few well-described phosphorylation/ dephosphorylation sites, such as as $\operatorname{Ser}^{1177}$ and $\mathrm{Thr}^{495}$. Some other sites regulating NOS activity $\left(\operatorname{Ser}^{633}, \operatorname{Ser}^{114}\right.$ and $\mathrm{Se}^{615}$ ) have been identified, but their precise roles remain controversial (Mount et al. 2007). These phosphorylation/dephosphorylation regulatory eNOS sites can be activated by multiple protein kinases, including PKA, PKB, PKC, AMPK, ERK and phosphatases such as protein phosphatase (PP)1 and 
PP2A in response to multiple stimuli via shear stress, growth factors, insulin, etc. (Fleming et al. 2001, Mount et al. 2007, Chen et al. 2009, Xiao et al. 2011).

Recent studies have suggested a potential regulatory role of PPAR $\gamma$-dependent eNOS expression and NO generation in the vascular endothelium. Several studies suggest that a direct transcriptional mechanism can be involved in PPAR $\gamma$-mediated release of NO in endothelial cells. The activation of PPAR $\gamma$ using 15d-PGJ2 or ciglitazone stimulates NO release from the endothelium (Calnek et al. 2003). Mechanisms of PPAR $\gamma$ activation-mediated increase in endothelial NO production are not yet understood.

Polikandriotis et al. (2005) suggested that PPAR $\gamma$-dependent eNOS activation is mediated via hsp90-dependent mechanism. RSG and 15d-PGJ2 stimulated hsp90-eNOS interaction, resulting in eNOS activation (at $\operatorname{Ser}^{1177}$ phosphorylation). Conversely, ciglitazone did not have this effect, which suggests different effects of PPAR $\gamma$ agonists. It seems that hsp90 probably plays a key role in this context because coadministration PPAR $\gamma$ agonist with geldanamycin (inhibitor of hsp90) attenuates eNOS activation and NO release from endothelial cells (Polikandriotis et al. 2005).

PPAR $\gamma$ activation decreases expression of NADPH oxidase subunits such as Nox1, gp91phox (Nox2) and Nox4, which is accompanied by an enhanced expression of SOD (superoxide dismutase) resulting in reduction of oxidative stress in the membrane of human umbilical vein endothelial cells. The elevated vascular oxidative stress reduces endothelial bioavailability of $\mathrm{NO}$ through peroxynitrite generation. Hwang et al. (2005) suggest that, NO release from endothelium due to PPAR $\gamma$ activation could enhance NO bioavailability by reducing endothelial superoxide anion and oxidative stress.

Endothelial dysfunction can be influenced with adiponectin. This hormonal protein, secreted in adipose tissue, can improve endothelial function via PPAR $\gamma$ activation-mediated eNOS phosphorylation. RSG administration to the diabetic mouse leads to the enhancement of NO bioavailability and the improvement in endothelial function through adiponectin release and subsequently activation of AMPK/eNOS and cAMP/PKA signaling pathways in the aorta (Wong et al. 2011).

Rho-kinase plays an important role in endothelial dysfunction development. This serine threonine kinase inactivates eNOS and reduces NO bioavailability (Budzyn et al. 2006, Nohria et al. 2006). PPAR $\gamma$ activation inhibits up-regulation of protein tyrosine phosphatase-2 (SHP-2) Rho-kinase. PIO administration in Ang II-treated cultured rat aortic smooth muscle cells up-regulates SHP-2 and subsequently dephosphorylates a GTP/GDP exchange factor of Rho-kinase Vav, resulting in the inactivation of Rho-kinase (Wakino et al. 2004).

Several studies suggest that PPAR $\gamma$ plays a distinctive role in regulation of eNOS expression in the endothelium, resulting in enhanced generation of vascular NO. PPAR $\gamma$ activation mediates vascular antiinflammatory and antioxidant response and regulates endothelial function. Therefore, it has a beneficial effect on the vascular function in patients with atherosclerosis and hypertension with or without diabetes mellitus (Polikandriotis et al. 2005, Duan et al. 2009, Yu et al. 2010). Moreover, the therapeutic opportunities of agents that activate PPAR $\gamma$ in preventing vascular endothelial dysfunction and cardiovascular disorders associated with endothelial dysfunction are discussed.

\section{PPAR $\gamma$ and renin-angiotensin system}

One PPAR $\gamma$-dependent mechanism, which can influence hypertension development, is the attenuation of $\mathrm{AT}_{1}$ receptor gene expression (Diep et al. 2002, Benkirane et al. 2006, Sugawara et al. 2010). This gene suppression of $\mathrm{AT}_{1}$ receptor is a result of protein-protein interaction between nuclear receptor PPAR $\gamma$ and $\mathrm{Sp} 1$ protein (specificity protein 1 transcription factor). Sp1 belongs to the class of zinc-finger motifs presented in transcription factors, which can join to GC rich promotor regions. PPAR $\gamma$ either down-regulates the expression of $\mathrm{AT}_{1}$ receptor and/or inhibits signaling pathways, such as PI3K and MAPK, through Ang II, PI3K and MAPK, suppressing thus ultimately the activation of RAS cascade (Wu et al. 2004, Benkirane et al. 2006) and remodeling of vascular wall (Benkirane et al. 2006).

RAS is an endocrine system that plays an essential role in cardiovascular and renal physiology. RAS regulates $\mathrm{BP}$ and the concentration of sodium ions (Rodrigues-Ferreira and Nahmias 2015). It also influences the sympathetic nervous system (SNS) functions and regulates extracellular fluid volume (Majzunova et al. 2013). Dysregulation of RAS participates in the pathogenesis of hypertension, atherosclerosis, ischemic heart disease and heart failure. Physiologically, the effect of RAS is mediated through Ang II, which is generated by an enzyme cascade and released to systemic circulation (Crowley and Coffman 2012). When BP in renal arteries 
decreases, cells of the juxtaglomerular apparatus produce and secrete a protease renin $(43 \mathrm{kDa})$. Renin is an endopeptidase and cleaves angiotensinogen to the decapeptide Ang I (angiotensin I). Elevated angiotensinogen concentration leads to supernormal Ang II production (Kobori et al. 2007). Ang II is a major stimulator of synthesis and secretion of aldosterone and activates SNS (Fleming et al. 2005). It is a mediator of oxidative stress, stimulates the production of cytokines, synthesis of adhesive molecules and stimulates vascular remodeling. Production of Ang II in the heart and in the vascular system significantly contributes to the pathogenesis of the cardiovascular diseases. Except for Ang II, Ang 1-7 (angiotensin 1-7) can be produced from Ang I through "alternative RAS axis". This alternative Ang 1-7 production is catalyzed by angiotensin-converting enzyme 2 (ACE2) (Santos et al. 2013).

Ang II binds to $\mathrm{AT}_{1}$ or $\mathrm{AT}_{2}$ receptors. They are associated with GPCR (G protein-coupled receptors. Similarly, it is associated with GPCR Mas receptor. Ang 1-7 is bound to Mas receptor. Activation of these receptors results in the phosphorylation of different signaling pathways, which often leads to opposite cellular roles. ACE/Ang II/AT 1 cascade mediates the major effects of Ang II. Activation of $\mathrm{AT}_{1}$ receptors stimulates L-type of calcium channels and through G-protein leads to activation of NADPH oxidase and to vasoconstriction response (Buchanan et al. 1995). Activation of $\mathrm{ACE} / \mathrm{Ang} \mathrm{II} / \mathrm{AT}_{2}$ cascade plays a role especially in prenatal period, when this cascade activation acts counter-regulatory to $\mathrm{AT}_{1}$ receptor. Activation of $\mathrm{AT}_{2}$ receptors results in anti-proliferative effect and leads to vasodilatation (Carey et al. 2000).

An increased expression of various components of the RAS during hypertension has been described in detail by Zicha et al. (2014). Several kinases are activated through Ang II-activated $\mathrm{AT}_{1}$ receptor, e.g. MAPK, p70S3 kinase, etc. This kinase activation is associated with BP increase and with hypertension development. $\mathrm{AT}_{1}$ receptor activation stimulates NADPH oxidase in vascular wall, which is major source of reactive oxygen species (ROS) (Touyz and Schiffrin 1999).

Gene expression of RAS molecules can be modulated also by PPAR (Fig. 2). PPAR $\gamma$ is expressed in the juxtaglomerular apparatus cells. Endogenous and pharmacological PPAR $\gamma$ ligands stimulate renin gene expression (Roszer and Ricote 2010).

Ligands of PPAR $\gamma$ can suppress the gene expression of ACE in vascular tissues (Efrati et al. 2007,
Takai et al. 2007, Song et al. 2008). In streptozotocininduced diabetes in rats, bezafibrate and PIO can equally protect against the streptozotocin-induced up-regulation of ACE in the aortic wall. Similarly, ACE gene expression is reduced by chronic treatment with RSG in obese Zucker rats (Song et al. 2008). Clinical studies have demonstrated that telmisartan inhibits ACE and blocks $\mathrm{AT}_{1}$ receptor, resulting in the vascular protection conferred to hypertensive type 2 diabetic patients by the anti-inflammatory and antiatherogenic consequences of PPAR activation (Unger and Stoppelhaar 2007).

Two Ang II receptor blockers, telmisartan and irbesartan, act as selective PPAR modulators (Sanchez et al. 2008, Tagami et al. 2009). Partial PPAR agonist telmisartan inhibits vascular ACE activity (Takai et al. 2007), $\mathrm{AT}_{1}$ receptor expression (Gosse 2006, Imayama et al. 2006) and increases endothelial NO synthesis (Kobayashi et al. 2008), preventing oxidative stress and endothelial dysfunction more effectively than non-PPARagonists among Ang II receptor blockers.

PPAR blocks the action of Ang II by transcriptionally repressing $\mathrm{AT}_{1}$ receptor gene expression in VSMCs (vascular smooth muscle cells) (Takeda et al. 2000, Imayama et al. 2006, Sanchez et al. 2008, Tagami et al. 2009). In addition to its role as a regulator of vascular tone, $\mathrm{AT}_{1}$ receptor activation contributes to vascular lesions and atherogenesis by promoting VSMC proliferation (Nishijo et al. 1998, Wakino et al. 2001). Therefore, a suppressed Ang II response can potentially slow the progression of atherosclerosis.

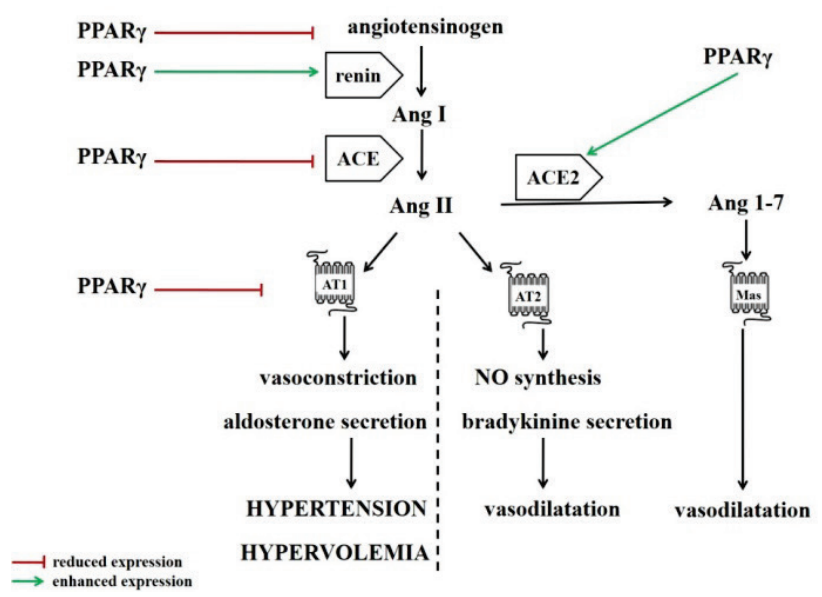

Fig. 2. Role of PPARY in the modulation of the RAS cascade, modified according to Roszer and Ricote (2010). Gene expression of RAS molecules is modulated by PPARy. Although renin production is facilitated by PPARY activation, the hypertensive effects of RAS activation are attenuated by PPARy ligands, since these strongly reduce Ang II levels, $A C E$ and $A T_{1}$ receptor gene expression. 
ACE inhibitor enalapril was tested on PPAR responses. Anthracycline therapy is limited by a cardiotoxicity that may eventually lead to chronic heart failure which is thought to be prevented by ACE inhibitors. Involvement of PPAR and changes in cellular metabolism in anthracycline cardiomyopathy has been investigated after enalaprilat administration to daunorubicin-treated Wistar rats. It was found that anthracycline administration significantly up-regulated PPAR $\alpha$ mRNA in the heart, but did not influence the expression of cardiac PPAR $\beta / \delta$. It the case of coadministration of ACE inhibitors the expression of cardiac PPAR $\alpha$ mRNA did not change, while the expression of $\mathrm{PPAR} \beta / \delta$ was increased. Altered expression of heart PPARs may suggest these nuclear receptors as a novel target in anthracycline cardiomyopathy (Cernecka et al. 2013).

\section{Phosphorylation cascades involved in RAS and PPAR $\gamma$ regulation}

Increased phosphorylation of signaling pathways participating on the growth and differentiation of cells is activated through Ang II. Ang II can subsequently activate PI3K and ERK 1/2 kinase and kinase cascades involved in these processes (Touyz and Schiffrin 1999).

PI3K activation via Ang II starts with phosphorylation of regulatory subunit $85 \alpha$ of PI3K. Subsequently, lipid phosphatase SHIP2 (Src homology 2 domain containing inositol 5-phosphatase 2) is activated. PI3K generates PIP3 and subsequently SHIP2 phosphatase hydrolyzes PIP3 to primary lipids, which are needed for activation of Akt kinase (Franke et al. 1997, Klippel et al. 1997, Scheid et al. 2002). Akt kinase is involved in mechanisms of cell survival, growth and vascular remodeling. Gingras et al. (1998) and Kitamura et al. (1998) suggested that the activation of PI3K/Akt cascade plays an important role in protein synthesis involved in vascular remodeling and hypertrophy, although Akt kinase is a kinase of "cell survival", because of its antiapoptotic effect (Downward 1998, Zhuang et al. 2011). Mechanisms of $\mathrm{AT}_{1}$ receptormediated PI3K-dependent activation of Akt kinase is not yet well understood, but it seems to play an important role in redox-sensitive signaling pathways and ROSmediated c-Src activation (Thomas and Brugge 1997, Ushio-Fukai et al. 1999). c-Src is cytoplasmic tyrosine kinase, which is activated especially via superoxide anions generated by NADPH oxidase.
Another kinase cascades activated through Ang II are mitogen-activated protein kinase (MAPK) cascades which are universal signal transduction modules. MAPKs are activated through Ang II are ERK $1 / 2$ (extracellular signal regulated kinase), JNK (c-Jun N-terminal kinase), p38, etc. (Robinson and Cobb 1997).

ERK $1 / 2$ participates on regulation of expression of growth and differentiation factors. Mechanism of ERK activation is not yet completely explained. Activation starts through $\beta$ and $\gamma$ subunits of $G$ protein and through receptor associated with tyrosine kinase Shc (Src homology domain) (Apostolidis and Weiss 1997, Berk and Corson 1997, Schieffer et al. 1997). Tyrosine kinase associated receptor stimulates joining p21ras receptor via a phosphorylation cascade. This receptor includes adaptor proteins with guanine nucleotide exchange factor. GDP/GTP exchange of $\mathrm{p} 21$ ras protein is stimulated through Shc-Grb2-Sos (son-of-sevenless) complex. Grb2 (growth factor receptor-bound protein 2) is stimulated by autophosphorylation of tyrosine kinase receptor. Serine c-Raf kinase is linked to plasma membrane with p21ras protein. Serine c-Raf kinase phosphorylates MEK (MAPK/ERK kinase). MEK dually phosphorylates threonine and tyrosine residues in Thr-Glu-Tyr motive, resulting in ERK $1 / 2$ activation (ERK 1: 44-kDa MAPK isoform; ERK 2: 42-kDa MAPK isoform) (Touyz and Schiffrin 2000). ERK 1/2 phosphorylation cascade plays a role in regulation of expression of growth and differentiation factors. In vitro studies suggested that PPAR $\gamma$ activation can inhibit activation of ERK 1/2 induced by Ang II (Goetze et al. 1999, Takeda et al. 2000, Diep et al. 2002, Fukuda et al. 2002).

\section{Effect of PPAR $\gamma$ on oxidative stress and cell stress response regulated by Nrf2}

Oxidative stress represents disruption of redox homeostasis for benefit of prooxidants, which exceed antioxidant capacity of cell, resulting in potential damage (Sies 2007). ROS produced in low concentration by different ROS sources in organism are an integral part of several intracellular signaling pathways during physiological processes (Touyz et al. 2003).

ROS are main contributors of oxidative stress in cells during physiological and pathological processes. The main enzyme sources of ROS include mitochondrial respiratory chain, nicotinamide adenine dinucleotide phosphate (NADPH) oxidases, xanthine oxidase and 
uncoupled NO synthase. They are controlled under physiological conditions using cell stress detection of Nrf2 signaling pathway. This cellular protection system is activated in pathophysiologic condition during oxidative and electrophilic stress (Elahi et al. 2009, Rodrigo et al. 2011, Touyz and Briones 2011).

The Keap1/Nrf2/ARE is a complex system maintaining redox homeostasis in normal or stress conditions. These signaling pathways consist from Nrf2 protein/nuclear factor, Keap1 protein and ARE element (antioxidant response element) (Nguyen et al. 2009). The Keap1 protein regulates negatively Nrf2 activity through cysteine residues which are sensitive to presence of ROS (Kang et al. 2004). During oxidative stress Nrf2 can be released from connection with Keap1 and is translocated to the nucleus where induces transcription of genes by ARE (Hur et al. 2010, Tkachev et al. 2011). ARE is present within regulatory areas of several cytoprotective target genes directly involved in the production of antioxidant and detoxification proteins (Reichard et al. 2007, Gardlik et al. 2011, Majzunova et al. 2013).

Further production of detoxification and antioxidant proteins is involved in the elimination of reactive oxidants and electrophilic products. These processes are performed through conjugation reactions detoxifying of xenobiotics by production of enzymes in detoxification phase II (e.g. glutathione-S-transferase, $\mathrm{NAD}(\mathrm{P}) \mathrm{H}$ : quinone oxidoreductase 1), direct inactivation of ROS and increasing the antioxidant capacity of cells (e.g. catalase, superoxide dismutase, heme oxigenase-1) and regulation of glutathione production (e.g. glutamatecysteine ligase) (Ishii et al. 2002, Gardlik et al. 2011, Hur and Gray 2011).

During chronic stress, some mechanisms appear to "switch off" Nrf2 activity. This process occurs after Nrf2 inactivation by aberrant phosphorylation by Fyn (fgr/yes novel protein) and GSK3 $\beta$ (glycogen synthase kinase $3 \beta$ ). GSK3 $\beta$ phosphorylates Fyn which affected phosphorylation of Nrf2 in nucleus. This action results in the export of Nrf2 from the nucleus to the cytosol and binding to Keap1 with the subsequent degradation of Nrf2 (Jain and Jaiswal 2006, Kanninen et al. 2011).

\section{Connection between PPAR $\gamma$ and Nfr2}

PPAR $\gamma$ maintains redox homeostasis by activation and repression of several signaling pathways. In the case of Nrf2 there is a reciprocal transcriptional regulation between genes of $\mathrm{Nrf2}$ and PPAR $\gamma$. Nrf2 contains putative PPREs and counter PPAR $\gamma$ gene contain ARE (Park et al. 2004, Cho et al. 2010). Experiments with Nrf2 null mice show that expression of PPAR $\gamma$ is reduced due to direct effect of Nrf2 lack. Nrf2 induces PPAR $\gamma$ expression by binding to at least two ARE sequences in the upstream promoter region of the nuclear receptor (Huang et al. 2010, Cho et al. 2010). Furthermore, Nrf2 expression is weakened in mice with decreased PPAR $\gamma$ (Park et al. 2004). A positive feedback loop between PPAR $\gamma$ and Nrf2 probably exists, where PPAR $\gamma$ may act directly or through upstream pathway for Nrf2 activation (Polvani et al. 2012). In addition, nuclear receptor PPAR $\gamma$ and transcription factor Nrf2 may act synergically in the activation of antioxidant genes (Ishii et al. 2004, Park et al. 2004). ARE and PPRE response element coexist in GSTA2 promoter. GSTA2 gene encodes detoxification enzyme glutathione S-transferase A2, where ARE site is important in the transactivation of the GSTA2 gene by PPAR $\gamma$ and RXR ligands for the full gene transactivation (Park et al. 2004). Similar expression of CD36 is dependent on both proteins, but transcription of CD36 may be induced independently by $\mathrm{Nrf} 2$ or PPAR $\gamma$, depending on the cellular context (Ishii et al. 2004).

There are another ways of activation and repression of antioxidant and prooxidant pathways. PPAR $\gamma$ creates a heterodimer with RXR and together regulate gene transcription (Desvergne and Wahli 1999, Varga et al. 2011). As dimers, PPAR $\gamma:$ RXR bind to PPRE located in the promoter region of target genes. PPAR $\gamma$ may directly modulate the expression of several antioxidant and prooxidant genes in response to oxidative stress. It was observed that ligand-activated PPAR $\gamma$ promotes the expression of manganese SOD (MnSOD) (Ding et al. 2007), GPx3 (Chung et al. 2009), the scavenger receptor CD36 (Ishii et al. 2004), heme oxygenase-1 (HO-1) (Kronke et al. 2007) and the mitochondrial uncoupling protein 2 (UCP2) (Chan et al. 2010), whereas it down-regulates COX-2 and iNOS (Zhao et al. 2006, Vandewalle et al. 2008, Polvani et al. 2012).

One mechanism of PPAR $\gamma$ action represents the coexistence of PPREs and ARE in the same genes. The expression of scavenger receptor CD36 (mediates the recognition and internalization of oxidized lipids, antioxidant enzymes catalase, HO-1 and mitochondrial MnSOD are transcriptionally regulated through PPREs (Ishii et al. 2004, Ding et al. 2007, Kronke et al. 2007). 


\section{Redox homeostasis disruption in cardiovascular diseases and the role of PPAR $\gamma$}

Disruption of redox homeostasis and pathophysiological ROS level leads to series of damage effects that participate in the development of cardiovascular diseases. Hypertension is a multifactorial complex disease leading to the damage of several organ systems. The factors participating in hypertension development include SNS activation, RAS up-regulation, altered $G$ protein-associated signalization and inflammation (Touyz 2005, Harris et al. 2008). Oxidative stress is a common factor of these processes. It affects processes participating in vascular remodeling, growth and proliferation of vascular smooth muscle cells, lipid peroxidation, extracellular matrix remodeling, fibrosis, monocyte invasion and inflammation. Moreover, increased ROS levels are associated with higher vascular contractility, vascular and cardiac fibrosis and remodeling, manifested by blood pressure elevation and cardiac output increase (Montezano and Touyz 2014).

Polvani et al. (2012) pointed out that nuclear receptor PPAR $\gamma$ can affect redox homeostasis by interacting with signaling pathways, including nuclear factor $\mathrm{Nrf} 2, \mathrm{NF}-\kappa \mathrm{B}, \mathrm{Wnt} / \beta$-catenin and FOXO proteins (Fig. 3).

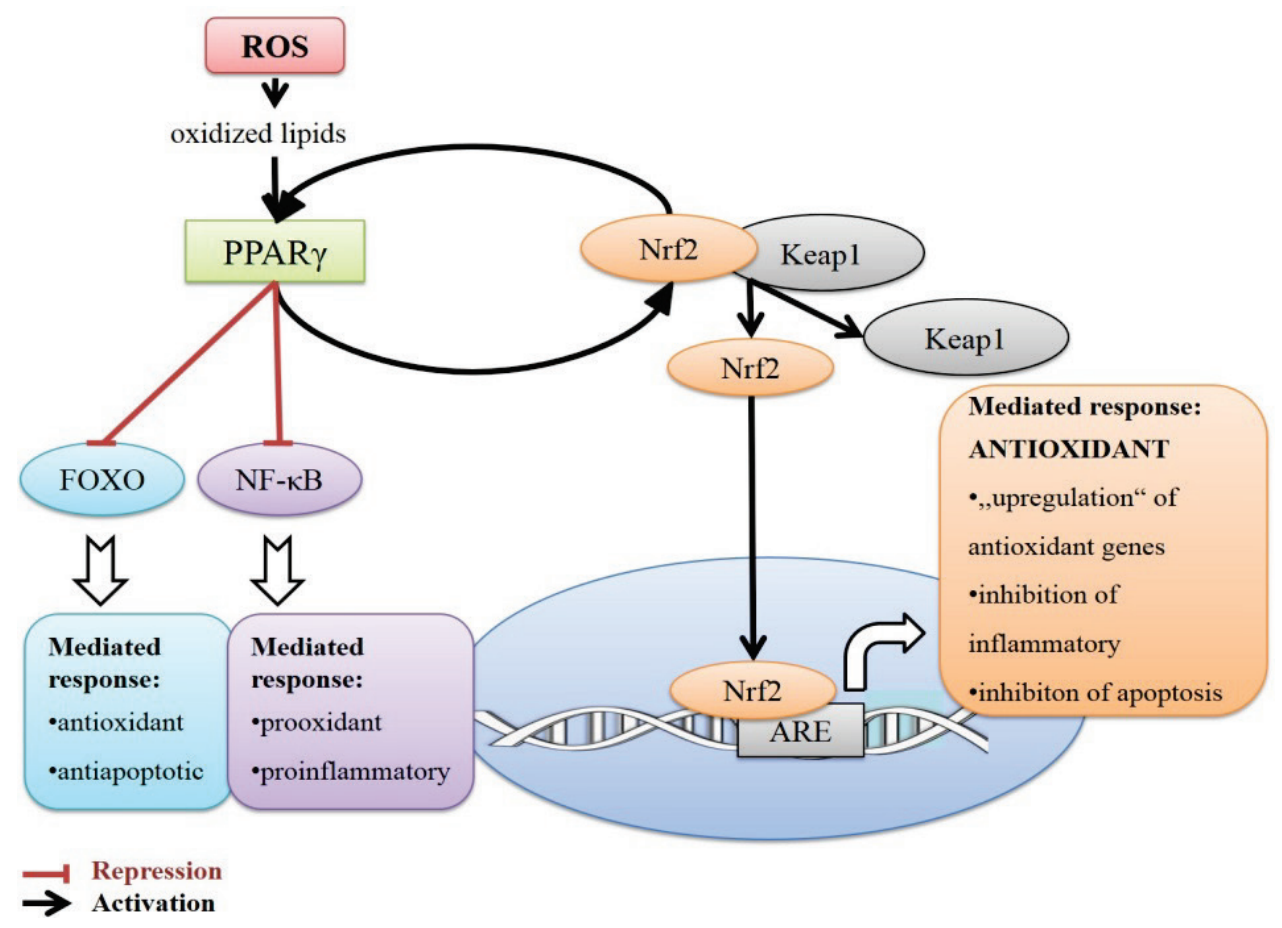

Fig. 3. Cross-talk of PPARy with other signaling pathways, such as nuclear factor Nrf2, NF-kB, Wnt/ $\beta$-catenin, FOXO proteins in oxidative stress response (modified according to Polvani et al. 2012).

In the pathogenesis of hypertension it was observed that ROS overproduction in the central nervous system increases SNS activation in peripheral vessels (Peters et al. 2000, Nagao and Yamaguchi 2012). Furthermore, increased $\mathrm{AT}_{1}$ receptor expression, almost localized on glutamatergic neurons in rostral ventrolateral medulla (RVLM), can modulate excitatory or inhibitory neurons and their postsynaptic activity (Hu et al. 2002). This can lead to higher SNS activity and positive correlation with BP (Dampney et al. 2007).

Moreover, ROS overproduction in the kidneys increases Ang II production and Ang II-mediated renal vasoconstriction (Just et al. 2008), renin release (Welch et al. 1983), renal nervous activity (Lai et al. 2012) as well as the activation of endothelin-1 and thromboxane (Wang et al. 2004).

TZDs treatment decreases ROS production in vascular smooth muscle cells (Dobrian et al. 2004, Ceolotto et al. 2007) and endothelial cells (Dobrian et al. 2004, Sorrentino et al. 2007), allowing the decrease in blood pressure. Chan et al. (2010) suggest that RSG administration shows central antihypertensive effect. With respect to the central role of oxidative stress in neural mechanisms of hypertension development (Peters 
et al. 2000, Kimura et al. 2005), the antihypertensive effect of RSG can be mediated through PPAR $\gamma$ dependent transcriptional up-regulation of antioxidant mechanisms in RVLM (Chan et al. 2010).

PPAR $\gamma$ protects against the apoptosis of cardiomyocytes and glial cells from oxidative stress by induction of transcription of Bcl-2 (B-Cell CLL/Lymphoma 2) (Ren et al. 2009).

In humans vessels, the expression of HO-1 is induced in the presence of oxidative stress and high glucose level after TZDs administration (Wang et al. 2011). Oxidative stress in RVLM, where sympathetic premotor neurons reside, contributes to sympathoexcitation and hypertension. Metabolic syndrome, which is activated in rats by high-fructose diet, increases sympathetic vasomotor activity, blood pressure and ROS level, while it reduces NO and mitochondrial electron transport capacity. Treatment of these animals by TZDs (PIO) abrogated all those molecular events in this model of metabolic syndrome and ameliorated sympathoexcitation and hypertension (Wu et al. 2014).

\section{Conclusions}

The PPAR $\gamma$ nuclear receptor is transactivated by its ligands and functions as an activator or repressor of a variety of signaling pathways. It may be also involved in insulin signaling regulation, RAS suppression, as well as in the regulation of antioxidant response, either directly or through the Nrf2 transcription factor.

PPAR $\gamma$ regulates a number of homeostatic functions of the glucose and lipid metabolism and, as a nutrient-sensing signaling sensor, it can influence nutritional programming to hypertension and/or metabolic syndrome. Several ligands of this receptor can potentiate its activation. Many exogenous ligands such as thiazolidinediones: rosiglitazone, pioglitazone or tideglusib have a range of positive effects on cardiovascular diseases and the metabolic syndrome, however, some of them have harmful side effects. The usefulness and effectiveness of PPAR $\gamma$ ligands on lifestyle-related diseases has yet to be established. Future investigations have to search for various endogenous ligands and their effects.

\section{Conflict of Interest}

There is no conflict of interest.

\section{Acknowledgements}

Supported by APVV-0348-12 and VEGA02/0129/14.

\section{Abbreviations}

(PP) 1 - protein phosphatase 1

15d-PGJ2 - 15-deoxy- $\Delta$-12,14-prostaglandin $\mathrm{J}_{2}$

$\mathrm{ACE}$ - angiotensin converting enzyme

AF-1 and AF-2 - activation function motive 1 and 2

Akt - Akt serine/threonine kinase 1

AMPK - AMP-activated protein kinase

Ang 1-7 - angiotensin 1-7

Ang I and Ang II - angiotensin I and II

ARE - antioxidant response element

$\mathrm{AT}_{1}$ and $\mathrm{AT}_{2}-$ angiotensin-receptor type 1 and 2

Bcl-2 - B-cell CLL/lymphoma 2

BMAL-1 - brain and muscle Arnt-like protein-1

$\mathrm{BP}$ - blood pressure

cAMP - cyclic adenosine 3', 5' monophosphate

CD36 - cluster determinant 36

COX-2 - cyclo-oxygenase 2

c-Src - c-Src tyrosine kinase

eNOS - endothelial nitric oxide synthase

ERK 1/2 - extracellular signal regulated kinase

ET-1 - endothelin 1

FGF - fibroblast growth factor

FOXO - forkhead box protein $\mathrm{O}$

Fyn - fgr/yes novel protein

GC rich promotors regions - guanine and cytosine rich promotors regions

GDP - guanosine diphosphate

GLUT4 - glucose transporter type 4

GPCR - G-protein-coupled receptors

GPx3 - glutathione peroxidase 3

Grb2 - growth factor receptor-bound protein 2

GSK-3 $\beta$ - glycogen synthase kinase-3beta

GSTA - glutathione S-transferase A2

GTP - guanosine-5'-triphosphate

HO-1 - heme oxygenase-1

iNOS - inducible nictric oxide synthase

IR - insulin receptor

IRS - insulin receptor substrate

JNK - c-Jun N-terminal kinase

Keap1 - Kelch-like ECH associated protein

MAPK - mitogen-activated protein kinase

Mas - Mas proto-oncogene, G protein-coupled receptor

MEK - MAPK/ERK kinase

$\mathrm{NCoR}$ - nuclear receptor corepressor

$\mathrm{NF}-\kappa \mathrm{B}$ - nuclear factor kappa B

$\mathrm{NO}$ - nitric oxide

Nox - NADPH oxidase

Nrf2 - Nuclear factor E2-related factor 2

PDK1 - 3' phosphoinositide-dependent kinase-1 
PI3K - phosphatidylinositol-3-kinase

PIO - pioglitazone

PIP2 - phosphatidylinositol 4,5-bisphosphate

PIP3 - phosphatidylinositol (3,4,5)-triphosphate

PKA, PKB and PKC - protein kinase A, B and C

PLC - phospholipase C

PP2A - protein phosphatase $2 \mathrm{~A}$

PPAR - peroxisome proliferator-activated receptor

PPRE - peroxisome proliferator response element

RAF - Raf-1 proto-oncogene, serine/threonine kinase

RAS - renin-angiotensin system

ROS - reactive oxygen species

$\mathrm{RSG}$ - rosiglitazone

RVLM - rostral ventrolateral medulla

$\mathrm{RXR}$ - retinoid $\mathrm{X}$ receptor

$\mathrm{SH} 2$ - src homology 2

Shc - Src homology domain
SHIP2 - Src homology 2 domain containing inositol 5-phosphatase 2

SHR - spontaneously hypertensive rats

SMRT - silencing mediator of retinoic acid and thyroid hormone receptor

SMRT - silencing mediator of retinoic acid and thyroid hormone receptor

SNS - sympathetic nervous system

SOD - superoxide dismutase

Sos - son-of-sevenless

Sp1 protein - specificity protein 1 transcription factor

STAT - signal transducers and activators of transcription

SUMO - small ubiquitin-like modifier

TZDs - thiazolidinediones

UCP2 - uncoupling protein 2

VSMC - vascular smooth muscle cells

Wnt - Wingless-type MMTV integration site

\section{References}

AGARWAL AK, GARG A: A novel heterozygous mutation in peroxisome proliferator-activated receptor-gamma gene in a patient with familial partial lipodystrophy. J Clin Endocrinol Metab 87: 408-411, 2002.

AHMADIAN M, DUNCAN RE, SUL HS: The skinny on fat: lipolysis and fatty acid utilization in adipocytes. Trends Endocrinol Metab 20: 424-428, 2009.

ANAN F, MASAKI T, FUKUNAGA N, TESHIMA Y, IWAO T, KANEDA K, UMENO Y, OKADA K, WAKASUGI K, YONEMOCHI H, ESHIMA N, SAIKAWA T, YOSHIMATSU H: Pioglitazone shift circadian rhythm of blood pressure from non-dipper to dipper type in type 2 diabetes mellitus. Eur J Clin Invest 37: 709-714, 2007.

APOSTOLIDIS A, WEISS RH: Divergence in the G-protein-coupled receptor mitogenic signalling pathway at the level of Raf kinase. Cell Signal 9: 439-445, 1997.

ARCE-ESQUIVEL AA, BUNKER AK, MIKUS CR, LAUGHLIN MH: Insulin resistance and endothelial dysfunction: Macro and microangiopathy. In: Type 2 Diabetes. MASUO K (ed), InTech, 2013, DOI: 10.5772/56475

ARMAGAN G, KESER A, ATALAYIN C, DAGCI T: Tideglusib protects neural stem cells against NMDA receptor overactivation. Pharmacol Rep 67: 823-831, 2015.

BARAK Y, NELSON MC, ONG ES, JONES YZ, RUIZ-LOZANO P, CHIEN KR, KODER A, EVANS RM: PPAR gamma is required for placental, cardiac, and adipose tissue development. Mol Cell 4: 585-595, 1999.

BARROSO I, GURNELL M, CROWLEY VE, AGOSTINI M, SCHWABE JW, SOOS MA, MASLEN GL, WILLIAMS TD, LEWIS H, SCHAFER AJ, CHATTERJEE VK, O'RAHILLY S: Dominant negative mutations in human PPARgamma associated with severe insulin resistance, diabetes mellitus and hypertension. Nature 402: 880-883, 1999.

BEENKEN A, MOHAMMADI M: The FGF family: biology, pathophysiology and therapy. Nat Rev Drug Discov 8: 235-253, 2009.

BENKIRANE K, VIEL EC, AMIRI F, SCHIFFRIN EL: Peroxisome proliferator-activated receptor gamma regulates angiotensin II-stimulated phosphatidylinositol 3-kinase and mitogen-activated protein kinase in blood vessels in vivo. Hypertension 47: 102-108, 2006.

BERK BC, CORSON MA: Angiotensin II signal transduction in vascular smooth muscle: role of tyrosine kinases. Circ Res 80: 607-616, 1997.

BUDZYN K, MARLEY PD, SOBEY CG: Targeting Rho and Rho-kinase in the treatment of cardiovascular disease. Trends Pharmacol Sci 27: 97-104, 2006. 
BUCHANAN TA, MEEHAN WP, JENG YY, YANG D, CHAN TM, NADLER JL, SCOTT S, RUDE RK, HSUEH WA: Blood pressure lowering by pioglitazone. Evidence for a direct vascular effect. J Clin Invest 96: 354-360, 1995.

BURRIS TP, BUSBY SA, GRIFFIN PR: Targeting orphan nuclear receptors for treatment of metabolic diseases and autoimmunity. Chem Biol 19: 51-59, 2012.

CALNEK DS, MAZZELLA L, ROSER S, ROMAN J, HART CM: Peroxisome proliferator-activated receptor gamma ligands increase release of nitric oxide from endothelial cells. Arterioscler Thromb Vasc Biol 23: 52-57, 2003.

CAMP HS, TAFURI SR: Regulation of peroxisome proliferator-activated receptor gamma activity by mitogenactivated protein kinase. J Biol Chem 272: 10811-10816, 1997.

CAREY RM, WANG ZQ, SIRAGY HM: Role of the angiotensin type 2 receptor in the regulation of blood pressure and renal function. Hypertension 35: 155-163, 2000.

CEOLOTTO G, GAllo A, PAPPARELla I, FRANCO L, MURPHY E, IORI E, PAGNIN E, FADINI GP, ALBIERO M, SEMPLICINI A, AVOGARO A: Rosiglitazone reduces glucose-induced oxidative stress mediated by NAD(P)H oxidase via AMPK-dependent mechanism. Arterioscler Thromb Vasc Biol 27: $2627-$ 2633, 2007.

CERNECKA H, OCHODNICKA-MACKOVICOVA K, KUCEROVA D, KMECOVA J, NEMCEKOVA V, DOKA G, KYSELOVIC J, KRENEK P, OCHODNICKY P, KLIMAS J: Enalaprilat increases PPAR $\beta / \delta$ expression, without influence on PPAR $\alpha$ and PPAR $\gamma$, and modulate cardiac function in sub-acute model of daunorubicininduced cardiomyopathy. Eur J Pharmacol 714: 472-427, 2013.

CHAN SH, WU KL, KUNG PS, CHAN JY: Oral intake of rosiglitazone promotes a central antihypertensive effect via upregulation of peroxisome proliferator-activated receptor-gamma and alleviation of oxidative stress in rostral ventrolateral medulla of spontaneously hypertensive rats. Hypertension 55: 1444-1453, 2010.

CHEN R, LIANG F, MORIYA J, YAMAKAWA JI, TAKAHASHI T, SHEN L, KAND T: Peroxisome proliferatoractivated receptors (PPARs) and their agonists for hypertension and heart failure: Are the reagents beneficial or harmful? Int J Cardiol 130: 131-139, 2008.

CHEN Y, JIMENEZ A R, MEDH JD: Identification and regulation of novel PPAR-gamma splice variants in human THP-1 macrophages. Biochim Biophys Acta 1759: 32-43, 2006.

CHEN Z, PENG IC, SUN W, SU MI, HSU PH, FU Y, ZHU Y, DEFEA K, PAN S, TSAI MD, SHYY JY: AMPactivated protein kinase functionally phosphorylates endothelial nitric oxide synthase Ser633. Circ Res 104: 496-505, 2009.

CHENG P, ZHANG F, YU L, LIN X, HE L, LI X, LU X, YAN X, TAN Y, ZHANG C: Physiological and pharmacological roles of FGF21 in cardiovascular diseases. J Diabetes Res 2016: 1540267, 2016.

CHO HY, GLADWELL W, WANG X, CHORLEY B, BELL D, REDDY SP, KLEEBERGER SR: Nrf2-regulated PPAR $\gamma$ expression is critical to protection against acute lung injury in mice. Am J Respir Crit Care Med 182: 170-182, 2010.

CHRISTODOULIDES C, VIDAL-PUIG A: PPARs and adipocyte function. Mol Cell Endocrinol 318: 61-68, 2010.

CHUNG S S, KIM M, YOUN B S, LEE N S, PARK J W, LEE I K, LEE Y S, KIM J B, CHO Y M, LEE H K, PARK K $\mathrm{S}$ : Glutathione peroxidase 3 mediates the antioxidant effect of peroxisome proliferator-activated receptor gamma in human skeletal muscle cells. Mol Cell Biol 29: 20-30, 2009.

COMPE E, DRANE P, LAURENT C, DIDERICH K, BRAUN C, HOEIJMAKERS JH, EGLY JM: Dysregulation of the peroxisome proliferator-activated receptor target genes by XPD mutations. Mol Cell Biol 25: 6065-6076, 2005.

COPPS KD, WHITE MF: Regulation of insulin sensitivity by serine/threonine phosphorylation of insulin receptor substrate proteins IRS1 and IRS2. Diabetologia 55: 2565-2582, 2012.

CROWLEY SD, COFFMAN TM: Recent advances involving the renin-angiotensin system. Exp Cell Res 318: 10491056, 2012.

DAMPNEY RA, TAN PS, SHERIFF MJ, FONTES MA, HORIUCHI J: Cardiovascular effects of angiotensin II in the rostral ventrolateral medulla: the push-pull hypothesis. Curr Hypertens Rep 9: 222-227, 2007.

DAS SK, CHAKRABARTI R: Role of PPAR in cardiovascular diseases. Recent Pat Cardiovasc Drug Discov 1: 193-209, 2006. 
DEFRONZO RA, GUNNARSSON R, BJORKMAN O, OLSSON M, WAHREN J: Effects of insulin on peripheral and splanchnic glucose metabolism in noninsulin-dependent (type II) diabetes mellitus. J Clin Invest 76: 149-155, 1985.

DESVERGNE B, WAHLI W: Peroxisome proliferator-activated receptors: nuclear control of metabolism. Endocr Rev 20: 649-688, 1999.

DIEP QN, EL MABROUK M, COHN JS, ENDEMANN D, AMIRI F, VIRDIS A, NEVES MF, SCHIFFRIN EL: Structure, endothelial function, cell growth, and inflammation in blood vessels of angiotensin II-infused rats: role of peroxisome proliferator-activated receptor-gamma. Circulation 105: 2296-2302, 2002.

DING G, FU M, QIN Q, LEWIS W, KIM HW, FUKAI T, BACANAMWO M, CHEN YE, SCHNEIDER MD, MANGELSDORF DJ, EVANS RM, YANG Q: Cardiac peroxisome proliferator-activated receptor gamma is essential in protecting cardiomyocytes from oxidative damage. Cardiovasc Res 76: 269-279, 2007.

DOBRIAN AD, SCHRIVER SD, KHRAIBI AA, PREWITT RL: Pioglitazone prevents hypertension and reduces oxidative stress in diet-induced obesity. Hypertension 43: 48-56, 2004.

DORMANDY JA, BETTERIDGE DJ, SCHERNTHANER G, PIRAGS V, NORGREN L, INVESTIGATORS P R: Impact of peripheral arterial disease in patients with diabetes - results from PROactive (PROactive 11). Atherosclerosis 202: 272-281, 2009.

DOVINOVA I, BARANCIK M, MAJZUNOVA M, ZORAD S, GAJDOSECHOVA L, GRESOVA L, CACANYIOVA S, KRISTEK F, BALIS P, CHAN JY: Effects of PPAR gamma agonist pioglitazone on redox-sensitive cellular signaling in young spontaneously hypertensive rats. PPAR Res 2013: 541871, 2013.

DOWNWARD J: Mechanisms and consequences of activation of protein kinase B/Akt. Curr Opin Cell Biol 10: 262-267, 1998.

DUAN SZ, IVASHCHENKO CY, RUSSELL MW, MILSTONE DS, MORTENSEN RM: Cardiomyocyte-specific knockout and agonist of peroxisome proliferator-activated receptor-gamma both induce cardiac hypertrophy in mice. Circ Res 97: 372-379, 2005.

DUAN SZ, IVASHCHENKO CY, WHITESALL SE, D'ALECY LG, DUQUAINE DC, BROSIUS FC, GONZALEZ FJ, VINSON C, PIERRE MA, MILSTONE DS, MORTENSEN RM: Hypotension, lipodystrophy, and insulin resistance in generalized PPARgamma-deficient mice rescued from embryonic lethality. J Clin Invest 117: 812-822, 2007.

DUAN SZ, USHER MG, MORTENSEN RM: PPARs: the vasculature, inflammation and hypertension. Curr Opin Nephrol Hypertens 18: 128-133, 2009.

DUTCHAK PA, KATAFUCHI T, BOOKOUT AL, CHOI JH, YU RT, MANGELSDORF DJ, KLIEWER SA: Fibroblast growth factor-21 regulates PPARgamma activity and the antidiabetic actions of thiazolidinediones. Cell 148: 556-567, 2012.

EFRATI S, BERMAN S, ILGIYEAV E, AVERBUKH Z, WEISSGARTEN J: PPAR-gamma activation inhibits angiotensin II synthesis, apoptosis, and proliferation of mesangial cells from spontaneously hypertensive rats. Nephron Exp Nephrol 106: e107-e112, 2007.

ELAHI MM, KONG YX, MATATA BM: Oxidative stress as a mediator of cardiovascular disease. Oxid Med Cell Longev 2: 259-269, 2009.

FISHER FM, CHUI PC, ANTONELLIS PJ, BINA HA, KHARITONENKOV A, FLIER JS, MARATOS-FLIER E: Obesity is a fibroblast growth factor 21 (FGF21)-resistant state. Diabetes 59: 2781-2789, 2010.

FLEMING I, FISSLTHALER B, DIMMELER S, KEMP BE, BUSSE R: Phosphorylation of Thr(495) regulates $\mathrm{Ca}^{2+} /$ calmodulin-dependent endothelial nitric oxide synthase activity. Circ Res 88: E68-E75, 2001.

FLEMING I, KOHLSTEDT K, BUSSE R: New fACEs to the renin-angiotensin system. Physiology (Bethesda) 20: 91-95, 2005.

FRANKE TF, KAPLAN DR, CANTLEY LC, TOKER A: Direct regulation of the Akt proto-oncogene product by phosphatidylinositol-3,4-bisphosphate. Science 275: 665-668, 1997.

FRUCHART JC, STAELS B, DURIEZ P: The role of fibric acids in atherosclerosis. Curr Atheroscler Rep 3: 83-92, 2001.

FU Z, GILBERT ER, LIU D: Regulation of insulin synthesis and secretion and pancreatic beta-cell dysfunction in diabetes. Curr Diabetes Rev 9: 25-53, 2013. 
FUKUDA N, HU WY, TENG J, CHIKARA S, NAKAYAMA M, KISHIOKA H, KANMATSUSE K: Troglitazone inhibits growth and improves insulin signaling by suppression of angiotensin II action in vascular smooth muscle cells from spontaneously hypertensive rats. Atherosclerosis 163: 229-239, 2002.

GARDLIK R, DOVINOVA I, CHAN J: Approaches in gene therapy of cancer and cardiovascular diseases In: Gene Therapy Applications. KANG C (ed), In Tech, 2011. DOI: 10.5772/18280

GINGRAS AC, KENNEDY SG, O'LEARY MA, SONENBERG N, HAY N: 4E-BP1, a repressor of mRNA translation, is phosphorylated and inactivated by the Akt(PKB) signaling pathway. Genes Dev 12: 502-513, 1998.

GOETZE S, XI XP, GRAF K, FLECK E, HSUEH WA, LAW RE: Troglitazone inhibits angiotensin II-induced extracellular signal-regulated kinase 1/2 nuclear translocation and activation in vascular smooth muscle cells. FEBS Lett 452: 277-282, 1999.

GOSSE P: A review of telmisartan in the treatment of hypertension: blood pressure control in the early morning hours. Vasc Health Risk Manag 2: 195-201, 2006.

GOVERS R, RABELINK TJ: Cellular regulation of endothelial nitric oxide synthase. Am J Physiol Renal Physiol 280: F193-F206, 2001.

HANKE S, MANN M: The phosphotyrosine interactome of the insulin receptor family and its substrates IRS-1 and IRS-2. Mol Cell Proteomics 8: 519-534, 2009.

HARRIS DM, COHN HI, PESANT S, ECKHART AD: GPCR signalling in hypertension: role of GRKs. Clin Sci (Lond) 115: 79-89, 2008.

HAUSER S, ADELMANT G, SARRAF P, WRIGHT HM, MUELLER E, SPIEGELMAN BM: Degradation of the peroxisome proliferator-activated receptor gamma is linked to ligand-dependent activation. $J$ Biol Chem 275 : 18527-18533, 2000.

HEGELE RA, CAO H, FRANKOWSKI C, MATHEWS ST, LEFF T: PPARG F388L, a transactivation-deficient mutant, in familial partial lipodystrophy. Diabetes 51: 3586-3590, 2002.

HU E, KIM JB, SARRAF P, SPIEGELMAN BM: Inhibition of adipogenesis through MAP kinase-mediated phosphorylation of PPARgamma. Science 274: 2100-2103, 1996.

HU L, ZHU DN, YU Z, WANG JQ, SUN ZJ, YAO T: Expression of angiotensin II type $1\left(\mathrm{AT}_{1}\right)$ receptor in the rostral ventrolateral medulla in rats. $J$ Appl Physiol 92: 2153-2161, 2002.

HUANG J, TABBI-ANNENI I, GUNDA V, WANG L: Transcription factor Nrf2 regulates SHP and lipogenic gene expression in hepatic lipid metabolism. Am J Physiol Gastrointest Liver Physiol 299: G1211-G1221, 2010.

HUR W, GRAY NS: Small molecule modulators of antioxidant response pathway. Curr Opin Chem Biol 15: 162-173, 2011.

HWANG J, KLEINHENZ DJ, LASSEGUE B, GRIENDLING KK, DIKALOV S, HART CM: Peroxisome proliferatoractivated receptor-gamma ligands regulate endothelial membrane superoxide production. Am J Physiol Cell Physiol 288: C899-C905, 2005.

IANKOVA I, PETERSEN RK, ANNICOTTE JS, CHAVEY C, HANSEN JB, KRATCHMAROVA I, SARRUF D, BENKIRANE M, KRISTIANSEN K, FAJAS L: Peroxisome proliferator-activated receptor gamma recruits the positive transcription elongation factor $\mathrm{b}$ complex to activate transcription and promote adipogenesis. $\mathrm{Mol}$ Endocrinol 20: 1494-1505, 2006.

IMAYAMA I, ICHIKI T, INANAGA K, OHTSUBO H, FUKUYAMA K, ONO H, HASHIGUCHI Y, SUNAGAWA $\mathrm{K}$ : Telmisartan downregulates angiotensin II type 1 receptor through activation of peroxisome proliferatoractivated receptor gamma. Cardiovasc Res 72: 184-190, 2006.

ISHII T, ITOH K, YAMAMOTO M: Roles of Nrf2 in activation of antioxidant enzyme genes via antioxidant responsive elements. Methods Enzymol 348: 182-190, 2002.

ISHII T, ITOH K, RUIZ E, LEAKE D S, UNOKI H, YAMAMOTO M, MANN GE: Role of Nrf2 in the regulation of CD36 and stress protein expression in murine macrophages: activation by oxidatively modified LDL and 4-hydroxynonenal. Circ Res 94: 609-616, 2004.

ISSEMANN I, GREEN S: Activation of a member of the steroid hormone receptor superfamily by peroxisome proliferators. Nature 347: 645-650, 1990.

JAIN AK, JAISWAL AK: Phosphorylation of tyrosine 568 controls nuclear export of Nrf2. J Biol Chem 281: 12132$12142,2006$. 
JONKER JW, SUH JM, ATKINS AR, AHMADIAN M, LI P, WHYTE J, HE M, JUGUILON H, YIN Y Q, PHILLIPS CT, YU RT, OLEFSKY JM, HENRY RR, DOWNES M, EVANS RM: A PPAR $\gamma$-FGF1 axis is required for adaptive adipose remodelling and metabolic homeostasis. Nature 485: 391-394, 2012.

JUST A, WHITTEN CL, ARENDSHORST WJ: Reactive oxygen species participate in acute renal vasoconstrictor responses induced by $\mathrm{ET}_{\mathrm{A}}$ and $\mathrm{ET}_{\mathrm{B}}$ receptors. Am J Physiol Renal Physiol 294: F719-F728, 2008.

KANNINEN K, WHITE AR, KOISTINAHO J, MALM T: Targeting glycogen synthase kinase-3beta for therapeutic benefit against oxidative stress in alzheimer's disease: involvement of the Nrf2-ARE pathway. Int $J$ Alzheimers Dis 2011: 985085, 2011.

KIM EK, CHOI EJ: Pathological roles of MAPK signaling pathways in human diseases. Biochim Biophys Acta 1802: 396-405, 2010.

KIM TH, KIM MY, JO SH, PARK JM, AHN YH: Modulation of the transcriptional activity of peroxisome proliferatoractivated receptor gamma by protein-protein interactions and post-translational modifications. Yonsei Med J 54: 545-559, 2013.

KIMURA Y, HIROOKA Y, SAGARA Y, ITO K, KISHI T, SHIMOKAWA H, TAKESHITA A, SUNAGAWA K: Overexpression of inducible nitric oxide synthase in rostral ventrolateral medulla causes hypertension and sympathoexcitation via an increase in oxidative stress. Circ Res 96: 252-260, 2005.

KISS M, CZIMMERER Z, NAGY L: The role of lipid-activated nuclear receptors in shaping macrophage and dendritic cell function: From physiology to pathology. J Allergy Clin Immunol 132: 264-286, 2013.

KITAMURA T, OGAWA W, SAKAUE H, HINO Y, KURODA S, TAKATA M, MATSUMOTO M, MAEDA T, KONISHI H, KIKKAWA U, KASUGA M: Requirement for activation of the serine-threonine kinase Akt (protein kinase B) in insulin stimulation of protein synthesis but not of glucose transport. Mol Cell Biol 18: 3708-3717, 1998.

KLIPPEL A, KAVANAUGH WM, POT D, WILLIAMS LT: A specific product of phosphatidylinositol 3-kinase directly activates the protein kinase Akt through its pleckstrin homology domain. Mol Cell Biol 17: 338-344, 1997.

KOBAYASHI N, OHNO T, YOSHIDA K, FUKUSHIMA H, MAMADA Y, NOMURA M, HIRATA H, MACHIDA Y, SHINODA M, SUZUKI N, MATSUOKA H: Cardioprotective mechanism of telmisartan via PPARgamma-eNOS pathway in Dahl salt-sensitive hypertensive rats. Am J Hypertens 21: 576-581, 2008.

KOBAYASHI T, TAGUCHI K, YASUHIRO T, MATSUMOTO T, KAMATA K: Impairment of PI3-K/Akt pathway underlies attenuated endothelial function in aorta of type 2 diabetic mouse model. Hypertension 44: 956-962, 2004.

KOBORI H, NANGAKU M, NAVAR LG, NISHIYAMA A: The intrarenal renin-angiotensin system: from physiology to the pathobiology of hypertension and kidney disease. Pharmacol Rev 59: 251-287, 2007.

KOH KK, QUON MJ, HAN SH, AHN JY, JIN DK, KIM HS, KIM DS, SHIN EK: Vascular and metabolic effects of combined therapy with ramipril and simvastatin in patients with type 2 diabetes. Hypertension 45: 1088-1093, 2005.

KOH KK, QUON MJ, HAN SH, CHUNG WJ, AHN JY, KIM JA, LEE Y, SHIN EK: Additive beneficial effects of fenofibrate combined with candesartan in the treatment of hypertriglyceridemic hypertensive patients. Diabetes Care 29: 195-201, 2006.

KOHLROSER J, MATHAI J, REICHHELD J, BANNER BF, BONKOVSKY HL: Hepatotoxicity due to troglitazone: report of two cases and review of adverse events reported to the United States Food and Drug Administration. Am J Gastroenterol 95: 272-276, 2000.

KRISHNASWAMI A, RAVI-KUMAR S, LEWIS JM: Thiazolidinediones: a 2010 perspective. Perm J 14: 64-72, 2010. KRONKE G, KADL A, IKONOMU E, BLUML S, FURNKRANZ A, SAREMBOCK IJ, BOCHKOV VN, EXNER M, BINDER BR, LEITINGER N: Expression of heme oxygenase-1 in human vascular cells is regulated by peroxisome proliferator-activated receptors. Arterioscler Thromb Vasc Biol 27: 1276-1282, 2007. 
KUBOTA T, KUBOTA N, KUMAGAI H, YAMAGUCHI S, KOZONO H, TAKAHASHI T, INOUE M, ITOH S, TAKAMOTO I, SASAKO T, KUMAGAI K, KAWAI T, HASHIMOTO S, KOBAYASHI T, SATO M, TOKUYAMA K, NISHIMURA S, TSUNODA M, IDE T, MURAKAMI K, YAMAZAKI T, EZAKI O, KAWAMURA K, MASUDA H, MOROI M, SUGI K, OIKE Y, SHIMOKAWA H, YANAGIHARA N, TSUTSUI M, TERAUCHI Y, TOBE K, NAGAI R, KAMATA K, INOUE K, KODAMA T, UEKI K, KADOWAKI T: Impaired insulin signaling in endothelial cells reduces insulin-induced glucose uptake by skeletal muscle. Cell Metab 13: 294-307, 2011.

LAI EY, SOLIS G, LUO Z, CARLSTROM M, SANDBERG K, HOLLAND S, WELlSTEIN A, WELCH WJ, WILCOX CS: p47(phox) is required for afferent arteriolar contractile responses to angiotensin II and perfusion pressure in mice. Hypertension 59: 415-420, 2012.

LEONARDINI A, LAVIOLA L, PERRINI S, NATALICCHIO A, GIORGINO F: Cross-talk between PPARgamma and insulin signaling and modulation of insulin sensitivity. PPAR Res 2009: 818945, 2009.

LI J, WANG N: Peroxisome proliferator-activated receptor-gamma in vascular biology. Cardiovasc Hematol Disord Drug Targets 7: 109-117, 2007.

LI R, ZHANG H, WANG W, WANG X, HUANG Y, HUANG C, GAO F: Vascular insulin resistance in prehypertensive rats: role of PI3-kinase/Akt/eNOS signaling. Eur J Pharmacol 628: 140-147, 2010.

LILLIOJA S, YOUNG AA, CULTER CL, IVY JL, ABBOTT WG, ZAWADZKI JK, YKI-JARVINEN H, CHRISTIN L, SECOMB TW, BOGARDUS C: Skeletal muscle capillary density and fiber type are possible determinants of in vivo insulin resistance in man. J Clin Invest 80: 415-424, 1987.

LINDI VI, UUSITUPA MI, LINDSTROM J, LOUHERANTA A, ERIKSSON JG, VALLE TT, HAMALAINEN H, ILANNE-PARIKKA P, KEINANEN-KIUKAANNIEMI S, LAAKSO M, TUOMILEHTO J, FINNISH DIABETES PREVENTION STUDY: Association of the Pro12Ala polymorphism in the PPAR- $\gamma 2$ gene with 3-year incidence of type 2 diabetes and body weight change in the Finnish Diabetes Prevention Study. Diabetes 51: 2581-2586, 2002.

MAJZUNOVA M, DOVINOVA I, BARANCIK M, CHAN JY: Redox signaling in pathophysiology of hypertension. J Biomed Sci 20: 69, 2013.

MITCHELL JA, ALI F, BAILEY L, MORENO L, HARRINGTON LS: Role of nitric oxide and prostacyclin as vasoactive hormones released by the endothelium. Exp Physiol 93: 141-147, 2008.

MONTANEZ JE, PETERS JM, CORRELL JB, GONZALEZ FJ, PATTERSON AD: Metabolomics: an essential tool to understand the function of peroxisome proliferator-activated receptor alpha. Toxicol Pathol 41: 410-418, 2013.

MONTEZANO AC, TOUYZ RM: Reactive oxygen species, vascular Noxs, and hypertension: focus on translational and clinical research. Antioxid Redox Signal 20: 164-182, 2014.

MORI H, IKEGAMI H, KAWAGUCHI Y, SEINO S, YOKOI N, TAKEDA J, INOUE I, SEINO Y, YASUDA K, HANAFUSA T, YAMAGATA K, AWATA T, KADOWAKI T, HARA K, YAMADA N, GOTODA T, IWASAKI N, IWAMOTO Y, SANKE T, NANJO K, OKA Y, MATSUTANI A, MAEDA E, KASUGA M: The Pro ${ }^{12}$-->Ala substitution in PPAR- $\gamma$ is associated with resistance to development of diabetes in the general population: possible involvement in impairment of insulin secretion in individuals with type 2 diabetes. Diabetes 50: 891-894, 2001

MOUNT PF, KEMP BE, POWER DA: Regulation of endothelial and myocardial NO synthesis by multi-site eNOS phosphorylation. J Mol Cell Cardiol 42: 271-279, 2007.

NAGAO S, YAMAGUCHI T: PPAR-gamma agonists in polycystic kidney disease with frequent development of cardiovascular disorders. Curr Mol Pharmacol 5: 292-300, 2012.

NAKAMURA T, USHIYAMA C, SHIMADA N, HAYASHI K, EBIHARA I, KOIDE H: Comparative effects of pioglitazone, glibenclamide, and voglibose on urinary endothelin-1 and albumin excretion in diabetes patients. J Diabetes Complications 14: 250-254, 2000.

NGUYEN T, NIOI P, PICKETT CB: The Nrf2-antioxidant response element signaling pathway and its activation by oxidative stress. J Biol Chem 284: 13291-13295, 2009.

NISHIJO N, SUGIYAMA F, KIMOTO K, TANIGUCHI K, MURAKAMI K, SUZUKI S, FUKAMIZU A, YAGAMI $\mathrm{K}$ : Salt-sensitive aortic aneurysm and rupture in hypertensive transgenic mice that overproduce angiotensin II. Lab Invest 78: 1059-1066, 1998. 
NISSEN SE, WOLSKI K: Effect of rosiglitazone on the risk of myocardial infarction and death from cardiovascular causes. N Engl J Med 356: 2457-2471, 2007.

NOHRIA A, GRUNERT ME, RIKITAKE Y, NOMA K, PRSIC A, GANZ P, LIAO J K, CREAGER MA: Rho kinase inhibition improves endothelial function in human subjects with coronary artery disease. Circ Res 99: 14261432, 2006.

OGIHARA T, SHIN BC, ANAI M, KATAGIRI H, INUKAI K, FUNAKI M, FUKUSHIMA Y, ISHIHARA H, TAKATA K, KIKUCHI M, YAZAKI Y, OKA Y, ASANO T: Insulin receptor substrate (IRS)-2 is dephosphorylated more rapidly than IRS-1 via its association with phosphatidylinositol 3-kinase in skeletal muscle cells. J Biol Chem 272: 12868-12873, 1997.

OLIVEIRA JM, REBUFFAT SA, GASA R, GOMIS R: Targeting type 2 diabetes: lessons from a knockout model of insulin receptor substrate 2. Can J Physiol Pharmacol 92: 613-620, 2014.

OSTGREN CJ, LINDBLAD U, MELANDER O, MELANDER A, GROOP L, RASTAM L: Peroxisome proliferatoractivated receptor- $\gamma$ Pro12Ala polymorphism and the association with blood pressure in type 2 diabetes: Skaraborg Hypertension and Diabetes Project. J Hypertens 21: 1657-1662, 2003.

OYEKAN A: PPARs and their effects on the cardiovascular system. Clin Exp Hypertens 33: 287-293, 2011.

PARK EY, CHO IJ, KIM SG: Transactivation of the PPAR-responsive enhancer module in chemopreventive glutathione S-transferase gene by the peroxisome proliferator-activated receptor-gamma and retinoid $\mathrm{X}$ receptor heterodimer. Cancer Res 64: 3701-3713, 2004.

PASCUAL G, FONG AL, OGAWA S, GAMLIEL A, LI AC, PERISSI V, ROSE DW, WILLSON TM, ROSENFELD MG, GLASS CK: A SUMOylation-dependent pathway mediates transrepression of inflammatory response genes by PPAR-gamma. Nature 437: 759-763, 2005.

PETERS SL, MATHY MJ, PFAFFENDORF M, VAN ZWIETEN PA: Reactive oxygen species-induced aortic vasoconstriction and deterioration of functional integrity. Naunyn-Schmiedebergs Arch Pharmacol 361: 127-133, 2000.

POLIKANDRIOTIS JA, MAZZELLA LJ, RUPNOW HL, HART CM: Peroxisome proliferator-activated receptor gamma ligands stimulate endothelial nitric oxide production through distinct peroxisome proliferator-activated receptor gamma-dependent mechanisms. Arterioscler Thromb Vasc Biol 25: 1810-1816, 2005.

POLVANI S, TAROCCHI M, GALLI A: PPARgamma and oxidative stress: con(beta) catenating NRF2 and FOXO. PPAR Res 2012: 641087, 2012.

RAJI A, SEELY EW, BEKINS SA, WILLIAMS GH, SIMONSON DC: Rosiglitazone improves insulin sensitivity and lowers blood pressure in hypertensive patients. Diabetes Care 26: 172-178, 2003.

REICHARD JF, MOTZ GT, PUGA A: Heme oxygenase-1 induction by NRF2 requires inactivation of the transcriptional repressor BACH1. Nucleic Acids Res 35: 7074-7086, 2007.

REN Y, SUN C, SUN Y, TAN H, WU Y, CUI B, WU Z: PPAR gamma protects cardiomyocytes against oxidative stress and apoptosis via Bcl-2 upregulation. Vascul Pharmacol 51: 169-174, 2009.

ROBINSON MJ, COBB MH: Mitogen-activated protein kinase pathways. Curr Opin Cell Biol 9: 180-186, 1997.

RODRIGO R, GONZALEZ J, PAOLETTO F: The role of oxidative stress in the pathophysiology of hypertension. Hypertens Res 34: 431-440, 2011.

RODRIGUES-FERREIRA S, NAHMIAS C: G-protein coupled receptors of the renin-angiotensin system: new targets against breast cancer? Front Pharmacol 6: 24, 2015.

ROSZER T, RICOTE M: PPARs in the renal regulation of systemic blood pressure. PPAR Res 2010: 698730, 2010.

SANCHEZ RA, MASNATTA LD, PESINEY C, FISCHER P, RAMIREZ AJ: Telmisartan improves insulin resistance in high renin nonmodulating salt-sensitive hypertensives. J Hypertens 26: 2393-2398, 2008.

SANTOS RA, FERREIRA AJ, VERANO-BRAGA T, BADER M: Angiotensin-converting enzyme 2, angiotensin(1-7) and Mas: new players of the renin-angiotensin system. J Endocrinol 216: R1-R17, 2013.

SARABIA V, RAMLAL T, KLIP A: Glucose uptake in human and animal muscle cells in culture. Biochem Cell Biol 68: 536-542, 1990.

SARABIA V, LAM L, BURDETT E, LEITER LA, KLIP A: Glucose transport in human skeletal muscle cells in culture. Stimulation by insulin and metformin. J Clin Invest 90: 1386-1395, 1992. 
SCHEID MP, HUBER M, DAMEN JE, HUGHES M, KANG V, NEILSEN P, PRESTWICH GD, KRYSTAL G, DURONIO V: Phosphatidylinositol $(3,4,5) \mathrm{P}_{3}$ is essential but not sufficient for protein kinase B (PKB) activation; phosphatidylinositol $(3,4) \mathrm{P}_{2}$ is required for PKB phosphorylation at Ser-473: studies using cells from SH2-containing inositol-5-phosphatase knockout mice. J Biol Chem 277: 9027-9035, 2002.

SCHIEFFER B, DREXLER H, LING BN, MARRERO MB: G protein-coupled receptors control vascular smooth muscle cell proliferation via pp60c-src and p21ras. Am J Physiol 272: C2019-C2030, 1997.

SEMPLE RK, MEIRHAEGHE A, VIDAL-PUIG AJ, SCHWABE JW, WIGGINS D, GIBBONS GF, GURNELL M, CHATTERJEE VK, O'RAHILLY S: A dominant negative human peroxisome proliferator-activated receptor (PPAR) $\alpha$ is a constitutive transcriptional corepressor and inhibits signaling through all PPAR isoforms. Endocrinology 146: 1871-1882, 2005.

SHARGORODSKY M, WAINSTEIN J, GAVISH D, LEIBOVITZ E, MATAS Z, ZIMLICHMAN R: Treatment with rosiglitazone reduces hyperinsulinemia and improves arterial elasticity in patients with type 2 diabetes mellitus. Am J Hypertens 16: 617-622, 2003.

SHARMA MD, GARBER AJ, FARMER JA: Role of insulin signaling in maintaining energy homeostasis. Endocr Pract 14: 373-380, 2008.

SHIMIZU M, YAMASHITA D, YAMAGUCHI T, HIROSE F, OSUMI T: Aspects of the regulatory mechanisms of PPAR functions: analysis of a bidirectional response element and regulation by sumoylation. Mol Cell Biochem 286: 33-42, 2006.

SIES H: Biological redox systems and oxidative stress. Cell Mol Life Sci 64: 2181-2188, 2007.

SONG J, LIU H, RESSOM HW, TIWARI S, ECELBARGER CM: Chronic rosiglitazone therapy normalizes expression of ACE1, SCD1 and other genes in the kidney of obese Zucker rats as determined by microarray analysis. Exp Clin Endocrinol Diabetes 116: 315-325, 2008.

SORRENTINO SA, BAHLMANN FH, BESLER C, MULLER M, SCHULZ S, KIRCHHOFF N, DOERRIES C, HORVATH T, LIMBOURG A, LIMBOURG F, FLISER D, HALLER H, DREXLER H, LANDMESSER U: Oxidant stress impairs in vivo reendothelialization capacity of endothelial progenitor cells from patients with type 2 diabetes mellitus: restoration by the peroxisome proliferator-activated receptor-gamma agonist rosiglitazone. Circulation 116: 163-173, 2007.

SUGAWARA A, URUNO A, KUDO M, MATSUDA K, YANG C W, ITO S: Effects of PPARgamma on hypertension, atherosclerosis, and chronic kidney disease. Endocr J 57: 847-852, 2010.

SUN K, SCHERER PE: The PPARgamma-FGF1 axis: an unexpected mediator of adipose tissue homeostasis. Cell Res 22: 1416-1418, 2012.

TAGAMI T, YAMAMOTO H, MORIYAMA K, SAWAI K, USUI T, SHIMATSU A, NARUSE M: A selective peroxisome proliferator-activated receptor-gamma modulator, telmisartan, binds to the receptor in a different fashion from thiazolidinediones. Endocrinology 150: 862-870, 2009.

TAIN YL, HSU CN, CHAN JY: PPARs link early life nutritional insults to later programmed hypertension and metabolic syndrome. Int J Mol Sci 17: 20, 2016. doi:10.3390/ijms17010020

TAKAI S, JIN D, KIMURA M, KIRIMURA K, SAKONJO H, TANAKA K, MIYAZAKI M: Inhibition of vascular angiotensin-converting enzyme by telmisartan via the peroxisome proliferator-activated receptor gamma agonistic property in rats. Hypertens Res 30: 1231-1237, 2007.

TAKEDA K, ICHIKI T, TOKUNOU T, FUNAKOSHI Y, IINO N, HIRANO K, KANAIDE H, TAKESHITA A: Peroxisome proliferator-activated receptor gamma activators downregulate angiotensin II type 1 receptor in vascular smooth muscle cells. Circulation 102: 1834-1839, 2000.

TANIGUCHI A, FUKUSHIMA M, SAKAI M, TOKUYAMA K, NAGATA I, FUKUNAGA A, KISHIMOTO H, DOI K, YAMASHITA Y, MATSUURA T, KITATANI N, OKUMURA T, NAGASAKA S, NAKAISHI S, NAKAI Y: Effects of bezafibrate on insulin sensitivity and insulin secretion in non-obese Japanese type 2 diabetic patients. Metabolism 50: 477-480, 2001.

THOMAS SM, BRUGGE JS: Cellular functions regulated by Src family kinases. Annu Rev Cell Dev Biol 13: 513-609, 1997.

TOUYZ RM: Molecular and cellular mechanisms in vascular injury in hypertension: role of angiotensin II. Curr Opin Nephrol Hypertens 14: 125-131, 2005. 
TOUYZ RM, BRIONES AM: Reactive oxygen species and vascular biology: Implications in human hypertension. Hypertens Res 34: 5-14, 2011.

TOUYZ RM, SCHIFFRIN EL: Ang II-stimulated superoxide production is mediated via phospholipase D in human vascular smooth muscle cells. Hypertension 34: 976-982, 1999.

TOUYZ RM, SCHIFFRIN EL: Signal transduction mechanisms mediating the physiological and pathophysiological actions of angiotensin II in vascular smooth muscle cells. Pharmacol Rev 52: 639-672, 2000.

TOUYZ RM, TABET F, SCHIFFRIN EL: Redox-dependent signalling by angiotensin II and vascular remodelling in hypertension. Clin Exp Pharmacol Physiol 30: 860-866, 2003.

UNGER T, STOPPELHAAR M: Rationale for double renin-angiotensin-aldosterone system blockade. Am J Cardiol 100: 25J-31J, 2007.

USHIO-FUKAI M, ALEXANDER RW, AKERS M, YIN Q, FUJIO Y, WALSH K, GRIENDLING KK: Reactive oxygen species mediate the activation of Akt/protein kinase B by angiotensin II in vascular smooth muscle cells. J Biol Chem 274: 22699-22704, 1999.

VAN BEEKUM O, FLESKENS V, KALKHOVEN E: Posttranslational modifications of PPAR-gamma: fine-tuning the metabolic master regulator. Obesity (Silver Spring) 17: 213-219, 2009.

VANDEWALLE B, MOERMAN E, LEFEBVRE B, DEFRANCE F, GMYR V, LUKOWIAK B, KERR CONTE J, PATTOU F: PPARgamma-dependent and -independent effects of rosiglitazone on lipotoxic human pancreatic islets. Biochem Biophys Res Commun 366: 1096-1101, 2008.

VARGA T, CZIMMERER Z, NAGY L: PPARs are a unique set of fatty acid regulated transcription factors controlling both lipid metabolism and inflammation. Biochim Biophys Acta 1812: 1007-1022, 2011.

WAKINO S, KINTSCHER U, KIM S, JACKSON S, YIN F, NAGPAL S, CHANDRARATNA RA, HSUEH WA, LAW RE: Retinoids inhibit proliferation of human coronary smooth muscle cells by modulating cell cycle regulators. Arterioscler Thromb Vasc Biol 21: 746-751, 2001.

WAKINO S, HAYASHI K, KANDA T, TATEMATSU S, HOMMA K, YOSHIOKA K, TAKAMATSU I, SARUTA T: Peroxisome proliferator-activated receptor gamma ligands inhibit Rho/Rho kinase pathway by inducing protein tyrosine phosphatase SHP-2. Circ Res 95: e45-e55, 2004.

WANG D, CHABRASHVILI T, WILCOX CS: Enhanced contractility of renal afferent arterioles from angiotensininfused rabbits: roles of oxidative stress, thromboxane prostanoid receptors, and endothelium. Circ Res 94 : 1436-1442, 2004.

WANG N, YANG G, JIA Z, ZHANG H, AOYAGI T, SOODVILAI S, SYMONS JD, SCHNERMANN JB, GONZALEZ FJ, LITWIN SE, YANG T: Vascular PPARgamma controls circadian variation in blood pressure and heart rate through Bmal1. Cell Metab 8: 482-491, 2008.

WANG X, WANG Z, LIU JZ, HU JX, CHEN HL, LI WL, HAI CX: Double antioxidant activities of rosiglitazone against high glucose-induced oxidative stress in hepatocyte. Toxicol In Vitro 25: 839-847, 2011.

WATERS SB, PESSIN JE: Insulin receptor substrate 1 and 2 (IRS1 and IRS2): what a tangled web we weave. Trends Cell Biol 6: 1-4, 1996.

WELCH WJ, OTT CE, GUTHRIE GP JR, KOTCHEN TA: Mechanism of increased renin release in the adrenalectomized rat. Adrenal insufficiency and renin. Hypertension 5 (Suppl I): I47-I52, 1983.

WILLSON TM, COBB JE, COWAN DJ, WIETHE RW, CORREA ID, PRAKASH SR, BECK KD, MOORE LB, KLIEWER SA, LEHMANN JM: The structure-activity relationship between peroxisome proliferator-activated receptor gamma agonism and the antihyperglycemic activity of thiazolidinediones. $J$ Med Chem 39: 665-668, 1996.

WONG WT, TIAN XY, XU A, YU J, LAU C W, HOO RL, WANG Y, LEE VW, LAM KS, VANHOUTTE PM, HUANG Y: Adiponectin is required for PPARgamma-mediated improvement of endothelial function in diabetic mice. Cell Metab 14: 104-115, 2011.

WU KL, CHAO YM, TSAY SJ, CHEN CH, CHAN SH, DOVINOVA I, CHAN J Y: Role of nitric oxide synthase uncoupling at rostral ventrolateral medulla in redox-sensitive hypertension associated with metabolic syndrome. Hypertension 64: 815-824, 2014.

WU L, WANG R, DE CHAMPLAIN J, WILSON TW: Beneficial and deleterious effects of rosiglitazone on hypertension development in spontaneously hypertensive rats. Am J Hypertens 17: 749-756, 2004. 
XIAO Z, WANG T, QIN H, HUANG C, FENG Y, XIA Y: Endoplasmic reticulum $\mathrm{Ca}^{2+}$ release modulates endothelial nitric-oxide synthase via extracellular signal-regulated kinase (ERK) 1/2-mediated serine 635 phosphorylation. J Biol Chem 286: 20100-20108, 2011.

YU J, ZHANG Z, LI Z, FENG X, HE L, LIU S, MAO J, WANG G, WANG X: Peroxisome proliferator-activated receptor-gamma (PPARgamma) agonist improves coronary artery endothelial function in diabetic patients with coronary artery disease. J Int Med Res 38: 86-94, 2010.

ZHANG B, BERGER J, ZHOU G, ELBRECHT A, BISWAS S, WHITE-CARRINGTON S, SZALKOWSKI D, MOLLER DE: Insulin- and mitogen-activated protein kinase-mediated phosphorylation and activation of peroxisome proliferator-activated receptor gamma. J Biol Chem 271: 31771-31774, 1996.

ZHAO Y, PATZER A, HERDEGEN T, GOHLKE P, CULMAN J: Activation of cerebral peroxisome proliferatoractivated receptors gamma promotes neuroprotection by attenuation of neuronal cyclooxygenase-2 overexpression after focal cerebral ischemia in rats. FASEB J 20: 1162-1175, 2006.

ZHUANG Z, ZHAO X, WU Y, HUANG R, ZHU L, ZHANG Y, SHI J: The anti-apoptotic effect of PI3K-Akt signaling pathway after subarachnoid hemorrhage in rats. Ann Clin Lab Sci 41: 364-372, 2011.

ZICHA J, DOBESOVA Z, BEHULIAK M, PINTEROVA M, KUNES J, VANECKOVA I: Nifedipine-sensitive blood pressure component in hypertensive models characterized by high activity of either sympathetic nervous system or renin-angiotensin system. Physiol Res 63: 13-26, 2014. 